\title{
Azacitidine and decitabine have different mechanisms of action in non-small cell lung cancer cell lines
}

This article was published in the following Dove Press journal:

Lung Cancer:Targets and Therapy

9 September 2010

Number of times this article has been viewed

\author{
Aaron N Nguyen' \\ Paul W Hollenbach' \\ Normand Richard ${ }^{2}$ \\ Antonio Luna-Moran' \\ Helen Brady ${ }^{2}$ \\ Carla Heise' \\ Kyle J MacBeth' \\ 'Celgene Corporation, San Francisco, \\ CA, USA; ${ }^{2}$ Celgene Corporation, \\ San Diego, CA, USA
}

\begin{abstract}
Azacitidine (AZA) and decitabine (DAC) are cytidine azanucleoside analogs with clinical activity in myelodysplastic syndromes (MDS) and potential activity in solid tumors. To better understand the mechanism of action of these drugs, we examined the effects of AZA and DAC in a panel of non-small cell lung cancer (NSCLC) cell lines. Of 5 NSCLC lines tested in a cell viability assay, all were sensitive to $\mathrm{AZA}\left(\mathrm{EC}_{50}\right.$ of $\left.1.8-10.5 \mu \mathrm{M}\right)$, while only $\mathrm{H} 1299$ cells were equally sensitive to DAC $\left(\mathrm{EC}_{50}\right.$ of $\left.5.1 \mu \mathrm{M}\right)$. In the relatively DAC-insensitive cell line A549, both AZA and DAC caused DNA methyltransferase I depletion and DNA hypomethylation; however, only AZA significantly induced markers of DNA damage and apoptosis, suggesting that mechanisms in addition to, or other than, DNA hypomethylation are important for AZA-induced cell death. Cell cycle analysis indicated that AZA induced an accumulation of cells in sub-G1 phase, whereas DAC mainly caused an increase of cells in G2/M. Gene expression analysis of AZA- and DAC-treated cells revealed strikingly different profiles, with many genes distinctly regulated by each drug. In summary, while both AZA and DAC caused DNA hypomethylation, distinct effects were demonstrated on regulation of gene expression, cell cycle, DNA damage, and apoptosis.
\end{abstract}

Keywords: apoptosis, azacitidine, decitabine, gene expression, non-small cell lung cancer

\section{Introduction}

Azacitidine (AZA) (5-azacytidine, Vidaza ${ }^{\circledR}$; Celgene Corporation, Summit, NJ) and decitabine (DAC) (2'-deoxy-5-azacytidine, Dacogen ${ }^{\circledR}$; Eisai Inc., Woodcliff Lake, NJ) are used clinically for the treatment of myelodysplastic syndromes (MDS), a heterogeneous group of bone marrow stem cell disorders. ${ }^{1,2}$ Both AZA and DAC are cytidine nucleoside analogs that become incorporated into newly synthesized DNA, where they bind DNA methyltransferases (DNMTs) in an irreversible, covalent manner. ${ }^{3,4}$ The sequestration of DNMTs prevents maintenance of the methylation state of DNA, leading to DNA hypomethylation. ${ }^{5,6}$ As a consequence, genes previously silenced by DNA hypermethylation can be re-expressed upon treating cancer cell lines with these DNMT inhibitors. ${ }^{7,8}$ Re-expression of aberrantly methylated genes involved in normal cell cycle control, differentiation, and apoptotic pathways is believed to contribute to the anticancer effects of these drugs. ${ }^{9}$

Clinical activities of AZA and DAC are best established in the hematological malignancies MDS and acute myeloid leukemia (AML), cancers with a high frequency of aberrantly methylated genes. ${ }^{10}$ Aberrant DNA methylation of genes involved in DNA repair, cell adhesion, cell cycle, and cell death has also been reported in multiple types of solid cancers, including colon, stomach, breast, ovary, kidney, and lung. ${ }^{11}$
Correspondence: Aaron N Nguyen Celgene Corporation, 1500 Owens Street, Suite 600, San Francisco,

CA 94158 , USA

Tel +l 4I5 8397028

$\mathrm{Fax}+|4| 58397011$

Email anguyen@celgene.com which permits unrestricted noncommercial use, provided the original work is properly cited. 
For example, in non-small cell lung cancer (NSCLC), hypermethylation of tumor suppressor genes RAS association domain family $1 \mathrm{~A}(R A S S F 1 A)$, adenomatous polyposis coli $(A P C)$, fragile histidine triad $(F H I T)$, and $p 16^{I N K 4 A}$ has been associated with poor survival. ${ }^{12-15}$ Clinical trials investigating the use of AZA and DAC in solid tumors have been reported, although response rates were poor. In a Phase I study of DAC in patients with cancers involving the lungs, esophagus, and pleura, no objective responses were observed. ${ }^{16}$ Similar outcomes were obtained with DAC in patients with other forms of solid tumors. ${ }^{17}$ In a Phase II trial of AZA in patients with solid tumors, the responses were minimal and transient. ${ }^{18}$ The clinical response rate was also low for the combination of AZA and phenylbutyrate in patients with refractory solid tumors. ${ }^{19}$

A better understanding of the mechanistic activities of AZA and DAC will provide insights into rational use of these agents as therapies for solid tumor patients, including potential uses as combination therapies, adjuvant therapies, and maintenance therapies. Here, we directly compared the in vitro effects of AZA and DAC on cell viability, DNMT1 protein levels, DNA methylation, DNA damage, apoptosis, cell cycle, and gene expression in NSCLC cell lines. Although AZA and DAC caused similar effects on DNA-mediated markers such as DNMT1 depletion and DNA methylation, the drugs showed very different effects on cell viability, DNA damage, apoptosis, cell cycle, and gene expression.

\section{Results}

\section{AZA and DAC have differential effects on NSCLC cell viability}

AZA and DAC were compared in a panel of 5 NSCLC cell lines (A549, H1975, H460, H23, and H1299) for their effects on cell viability (Figure 1 and Supporting Information Figure 1). AZA reduced cell viability by at least $75 \%$ at high concentrations, with $\mathrm{EC}_{50}$ values of 1.8-10.5 $\mu \mathrm{M}$ (Table 1). In contrast, DAC did not reduce cell viability more than $55 \%$, and $\mathrm{EC}_{50}$ values were not reached in 4 (A549, H1975, H460, and H23) of the 5 NSCLC cell lines tested. In H1299
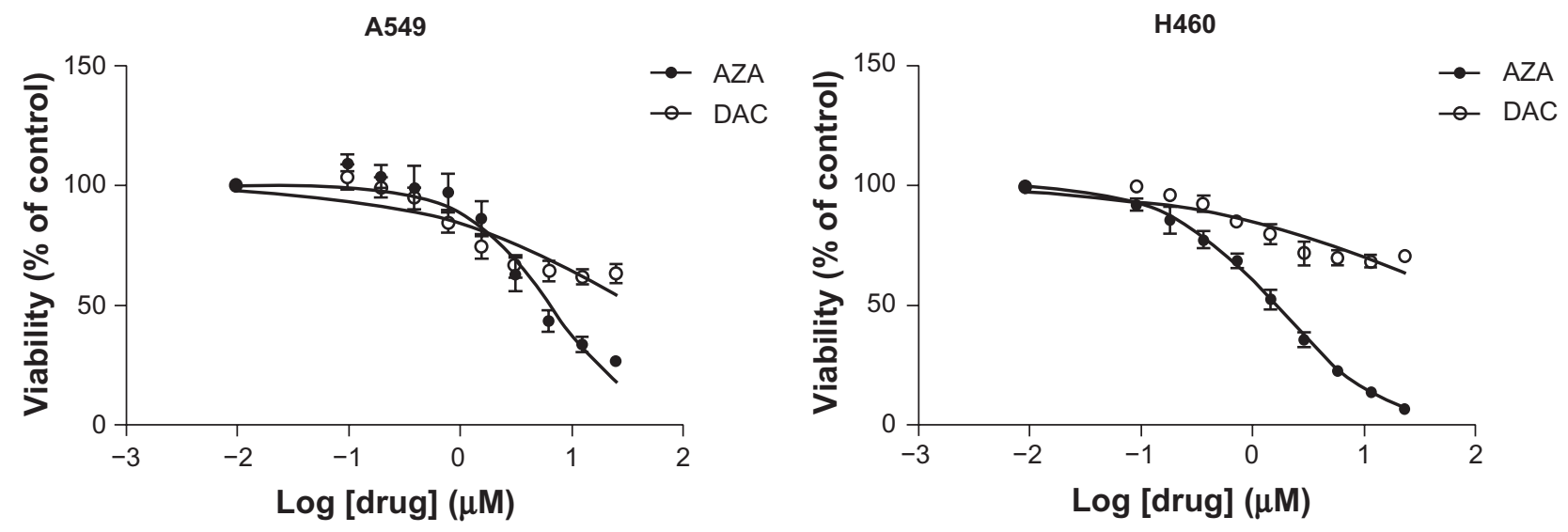

H1299

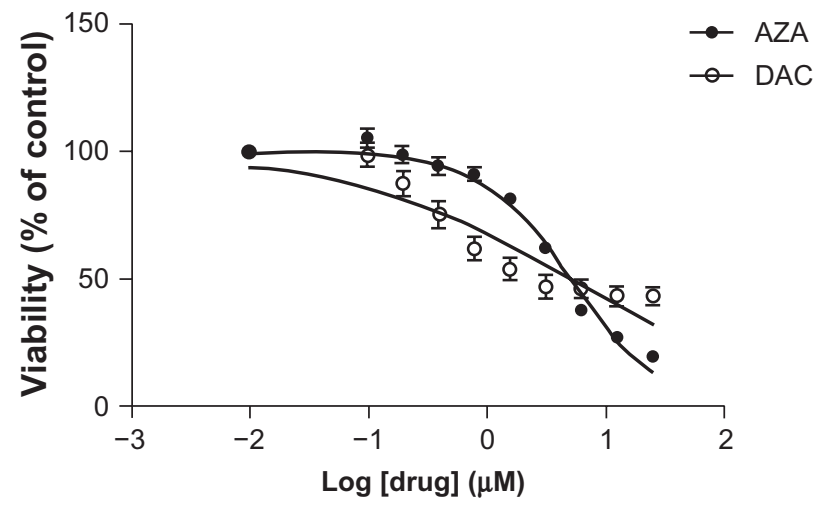

Figure I AZA and DAC differentially affect cell viability in a panel of NSCLC cell lines. Viability of A549, H460, and HI299 cells was assessed after 72 hours of treatment with AZA or DAC $(0-25 \mu \mathrm{M})$. Error bars represent the standard error of mean of 3 independent experiments, with triplicate wells per experiment. Abbreviations: AZA, azacitidine; DAC, decitabine; NSCLC, non-small cell lung cancer. 
Table I EC El $_{50}$ values for AZA and DAC on NSCLC cell viability

\begin{tabular}{lll}
\hline & AZA EC $_{50} \pm$ SEM $(\mu M)$ & DAC EC $_{50} \pm$ SEM $(\mu M)$ \\
\hline A549 & $6.3 \pm 1.1$ & $>25$ \\
$\mathrm{H} 1975$ & $8.6 \pm 2.9$ & $>25$ \\
$\mathrm{H} 460$ & $1.8 \pm 0.3$ & $>25$ \\
$\mathrm{H} 23$ & $10.5 \pm 1.8$ & $>25$ \\
$\mathrm{H} 1299$ & $5.1 \pm 0.2$ & $5.9 \pm 2.1$ \\
\hline
\end{tabular}

Note: $\mathrm{EC}_{50}$ values were calculated from 3 independent experiments using Graphpad Prism software.

Abbreviations: AZA, azacitidine; DAC, decitabine; NSCLC, non-small cell lung cancer.

cells, DAC EC $\mathrm{E}_{50}$ values were calculated; however, the $95 \%$ confidence intervals for the $\mathrm{EC}_{50}$ values were poor (data not shown). The $\mathrm{EC}_{50}$ values for AZA and DAC are similar to those reported for drugs commonly used in NSCLC, including gemcitabine, cisplatin, and carboplatin. ${ }^{20-22}$ The distinct dose-response curves and $\mathrm{EC}_{50}$ values indicate differential sensitivities of these NSCLC cell lines to AZA and DAC.

\section{AZA and DAC cause DNMTI depletion and DNA hypomethylation}

To determine whether the differential sensitivities of NSCLC cell lines to AZA versus DAC in cell viability assays reflected differences in the incorporation of each drug into DNA, DNMT1 protein depletion and DNA hypomethylation were evaluated as indirect measures of drug incorporation into DNA. When A549 and H1299 cells were treated with AZA or DAC for 20 hours, DNMT1 protein levels were reduced (Figure 2). Dose-dependent decreases in DNMT1 protein were observed

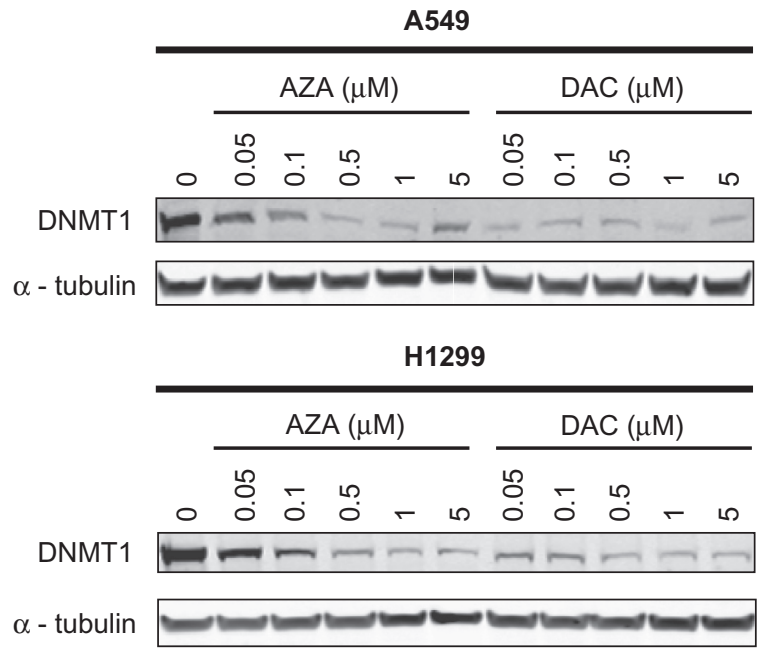

Figure 2 AZA and DAC cause DNMTI depletion in NSCLC cell lines. A549 and HI299 cells were treated with AZA or DAC $(0-5 \mu \mathrm{M})$ for 20 hours and DNMTI protein was detected by Western blotting of cell extracts. Alpha-tubulin was used as a loading control.

Abbreviations: AZA, azacitidine; DAC, decitabine; DNMTI, DNA methyltransferase I; NSCLC, non-small cell lung cancer. with AZA, while near-maximal reduction of DNMT1 protein was observed at the lowest concentration $(0.05 \mu \mathrm{M})$ of DAC. In A549 cells, DNMT1 depletion caused by $5 \mu \mathrm{M}$ AZA was not as much as that caused by 0.5 or $1 \mu \mathrm{M}$ AZA, possibly as a consequence of cell growth inhibition at the higher AZA concentration. ${ }^{23}$ Reduced DNMT1 levels were detected as early as 4 hours after drug treatment (Supporting Information Figure 2). Similar results were obtained in the $\mathrm{H} 460$ and $\mathrm{H} 23$ cell lines (data not shown).

We next determined whether AZA and DAC caused DNA hypomethylation by examining the methylation status of LINE-1 elements in A549 and H1299 cells treated for 48 hours (Figure 3) or 72 hours (Supporting Information Figure 3). Both AZA and DAC decreased LINE-1 methylation; however, DAC was 3- to 10-fold more potent. Peak hypomethylation was observed at $0.3-1.0 \mu \mathrm{M} \mathrm{AZA}$ and $0.1 \mu \mathrm{M}$ DAC LINE-1 methylation was unaffected at the highest DAC
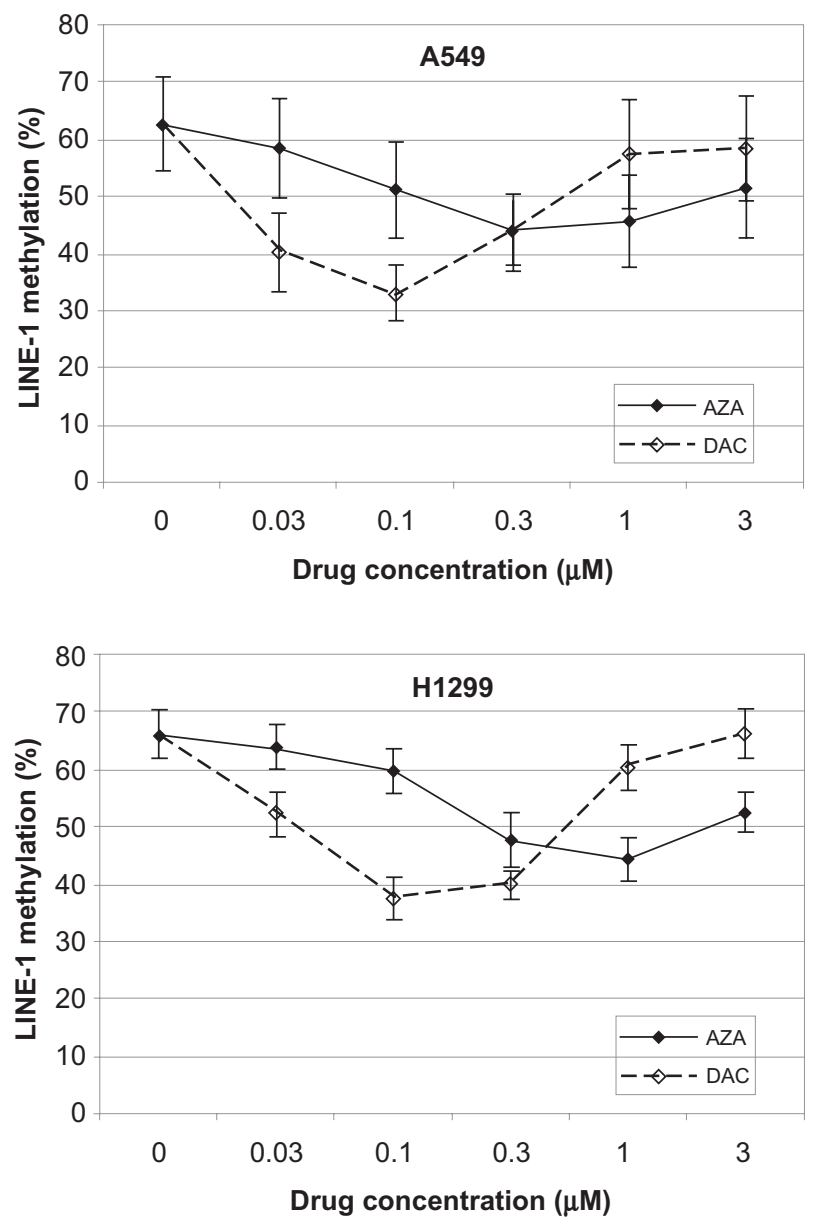

Figure 3 AZA and DAC reduce DNA methylation in A549 and HI299 cells. LINE-I DNA methylation was assessed in A549 and HI299 cells after 48 hours of treatment with AZA or DAC $(0-3 \mu \mathrm{M})$. Percentage LINE-I methylation represents the average percentage methylation of $4 C_{P} G$ sites in duplicate samples, with error bars representing the standard deviation.

Abbreviations: AZA, azacitidine; DAC, decitabine. 
concentration tested, possibly as a consequence of cell growth inhibition. ${ }^{23}$ DAC modulated the DNA-mediated markers (DNMT1 depletion and DNA hypomethylation) in both cell lines, suggesting that the relative insensitivity to DAC in cell viability assays cannot be attributed to a lack of drug uptake, phosphorylation, and DNA incorporation. These findings rule out dysfunctional deoxycytidine kinase, the rate-limiting kinase in the phosphorylation of DAC, as a possible mechanism of relative DAC-insensitivity, ${ }^{24}$ and suggest that mechanisms in addition to DNA incorporation are responsible for the greater sensitivity of NSCLC cell viability to AZA.

\section{AZA, but not DAC, robustly induces markers of DNA damage and apoptosis}

Phase contrast images of A549 cell cultures after 3 days of drug treatment showed reduced cell numbers and increased debris in AZA-treated cell cultures, but healthy-looking cells in DAC-treated cultures (Figure 4). These findings confirmed results of the cell viability assays (Figure 1). To examine the mechanism(s) of drug-induced cell death, A549 and H1299 NSCLC cell lines were treated with AZA or DAC for 24 or 48 hours, and markers of double-strand DNA (dsDNA) damage (histone-H2AX(ser139) phosphorylation) and apoptosis (PARP cleavage) were evaluated by Western blot (Figure 5 and data not shown). AZA dose-dependently induced histone-H2AX(ser139) phosphorylation and PARP cleavage in A549 cells. Similar results were observed in the H460 cell line (data not shown). There was relatively high basal phosphorylation of histone-H2AX(ser139) in H1299 cells, which was further increased by $10 \mu \mathrm{M}$ AZA.
High concentrations of AZA also induced PARP cleavage in H1299 cells. In A549 and H1299 cells, DNMT1 protein was completely depleted by DAC treatment; however, neither histone-H2AX(ser139) phosphorylation nor PARP cleavage were induced.

As AZA induced PARP cleavage, we further examined early-apoptotic (AnnexinV-FITC ${ }^{+}$and 7-AAD ${ }^{-}$) and lateapoptotic (AnnexinV-FITC ${ }^{+}$and $7-\mathrm{AAD}^{+}$) cell populations by flow cytometry in A549 and H1299 cells treated with AZA $(3 \mu \mathrm{M})$ or DAC ( $3 \mu \mathrm{M})$ for 72 hours (Figure 6). AZA (3 $\mu \mathrm{M})$ treatment of A549 and H1299 cells caused a significant increase in the early- and late-apoptotic populations (Figures 6B and 6C). DAC did not significantly cause an increase in these populations. These results demonstrated that AZA, but not DAC, induced dsDNA damage and apoptosis in NSCLC cell lines.

\section{DAC-treated HI 299 cells show delayed DNA damage response}

AZA and DAC appear to be incorporated into DNA of NSCLC cell lines, as both drugs induced DNMT1 depletion (Figure 2) and DNA hypomethylation (Figure 3). It was therefore surprising that 48-hour treatment with DAC did not induce dsDNA damage (histone-H2AX(ser139) phosphorylation) in A549 and H1299 cells (Figure 5). To better define the DNA damage response of NSCLC cell lines treated with AZA and DAC, we treated NSCLC cell lines with the drugs for an extended period of time. A549 and H1299 cells were treated with AZA or DAC for 6 days and lysates were collected on days 3 and 6 (Figure 7). At the 3-day time point in both cell lines, the results were
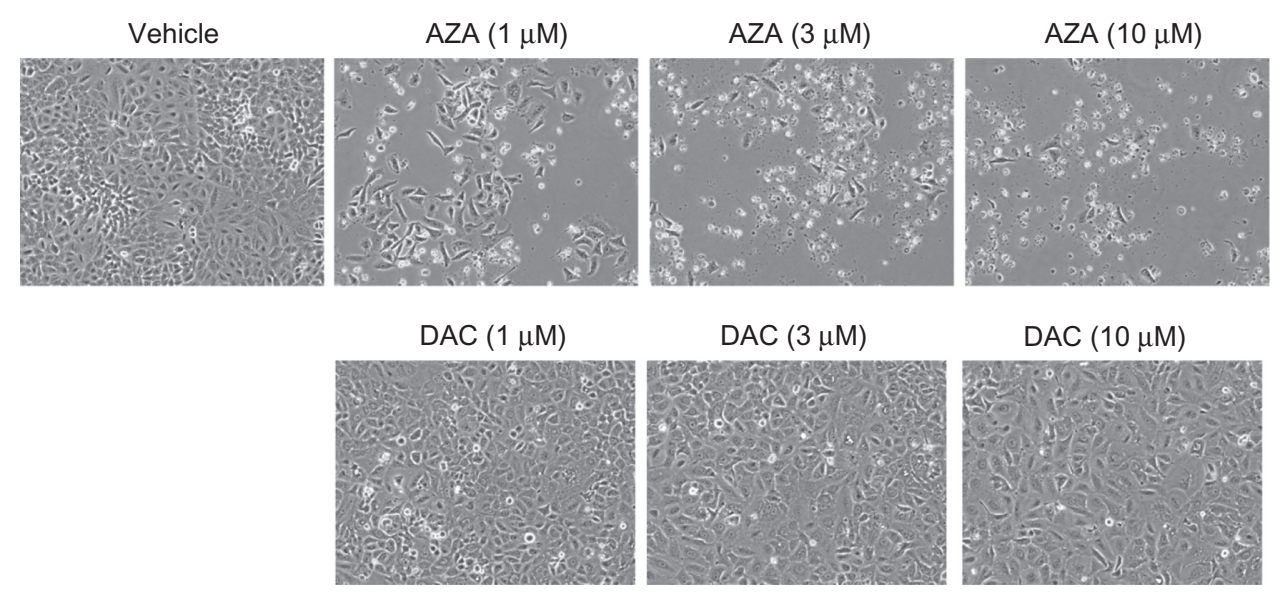

Figure 4 AZA-treated A549 cultures show reduced cell numbers. A549 cells, seeded in 6-well plates, were treated with vehicle or I, 3, and I0 $\mu$ M AZA or DAC for 72 hours. The CooISNAP ES2 CCD camera (Photometrics) was used to take phase-contrast images of cells under the Plan Fluor I0X objective (Nikon) on the Eclipse Ti-S microscope (Nikon).

Abbreviations: AZA, azacitidine; DAC, decitabine. 


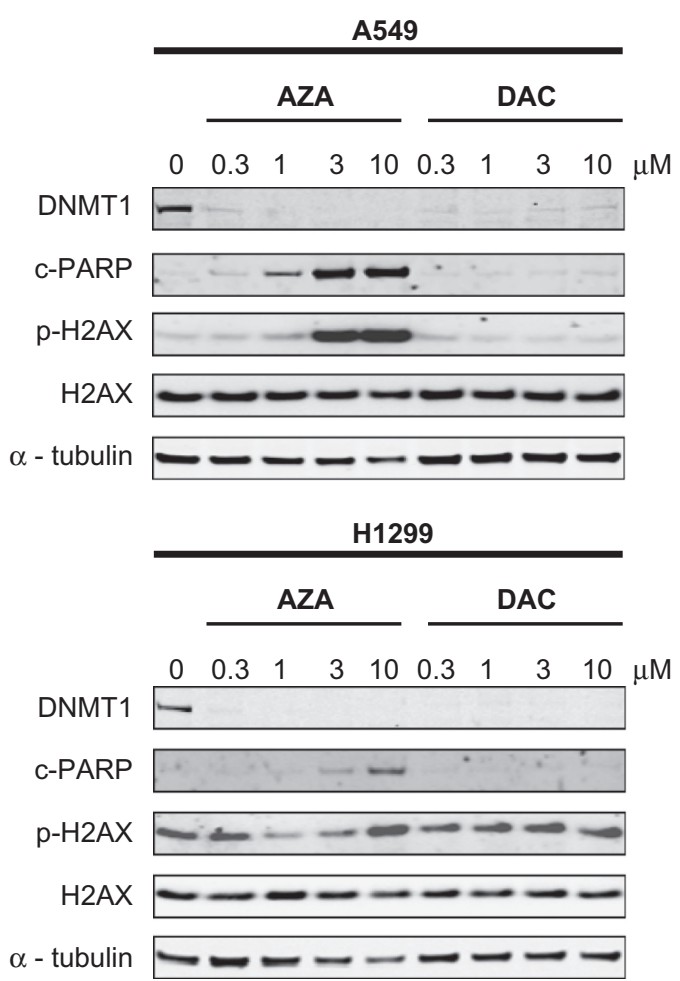

Figure 5 AZA, but not DAC, induces markers of DNA damage and apoptosis in NSCLC cell lines. A549 and HI299 cells were treated with AZA or DAC (0-10 $\mu \mathrm{M})$ for 48 hours and Western blotting of cell extracts was used to detect DNMTI, cleaved-PARP, phospho-histone-H2AX(ser/39), and total histone-H2AX. alphatubulin was used as a loading control.

Abbreviations: AZA, azacitidine; DAC, decitabine; DNMTI, DNA methyltransferase I; NSCLC, non-small cell lung cancer.

similar to those at the 24- and 48-hour time points; AZA, but not DAC, induced histone-H2AX(ser139) phosphorylation and PARP cleavage. In A549 cells, even after 6 days of daily treatment with DAC, there was no induction of histone-H2AX(ser139) phosphorylation and PARP cleavage (Figure 7). The $\mathrm{EC}_{50}$ values for $\mathrm{AZA}$ and DAC were $4.4 \mu \mathrm{M}$ and $2.5 \mu \mathrm{M}$, respectively, for A549 cells after 6 days of treatment (Supporting Information Table 1). Although the calculated $\mathrm{EC}_{50}$ value for DAC was lower than that of AZA, DAC did not reduce cell viability more than $75 \%$, while AZA almost completely inhibited cell viability (Supporting Information Figure 4). In H1299 cells, substantial histone-H2AX(ser139) phosphorylation, without much effect on PARP cleavage, was observed after 6 days of DAC treatment (Figure 7). Consistent with these results, phase contrast images of $\mathrm{H} 1299$ cells treated with DAC for a prolonged period did not show many cells undergoing apoptosis. Rather, prolonged treatment of H1299 cells resulted in fewer cells that are enlarged (data not shown). These results suggest that DAC may have a delayed effect on inducing DNA damage in NSCLC cell lines.

\section{AZA and DAC differentially affect the cell cycle}

The effects of AZA and DAC on cell cycle distribution were evaluated in A549 and H1299 cells treated for 72 hours (Figure 8). AZA dose-dependently increased the sub-G1 population in A549 cells, consistent with the induction of apoptosis (Figures 4-6). AZA also caused a minor increase in the sub-G1 population in H1299 cells (Figure 8), consistent with the induction of early-, rather than late-, apoptotic cell population at this time point (Figure 6). DAC also caused a minor increase in the sub-G1 population in these cell lines; however, the more prominent effect of DAC was an increase in the G2/M population.

\section{AZA and DAC modulate expression of different sets of genes}

Although both AZA and DAC caused DNMT1 depletion and DNA hypomethylation in NSCLC cell lines, the drugs had very different effects on cell viability, DNA damage, apoptosis, and cell cycle. To better understand the molecular pathways regulated by each drug, A549 and H1299 cells were treated with a dose range $(0.3-3.0 \mu \mathrm{M})$ of AZA or DAC for 48 hours, and effects on gene expression were assessed by microarray analysis. The total number of genes regulated by AZA or DAC, and the overlap of regulated genes, are presented in Table 2. At the lower drug concentration $(0.3 \mu \mathrm{M}), \mathrm{AZA}$ and DAC modulated few genes, with DAC modulating 4- to 20-fold more genes than AZA. At the higher drug concentrations ( 1 and $3 \mu \mathrm{M}$ ), many more genes were modulated, with AZA typically modulating 2 - to 5 -fold more genes than DAC. Interestingly, the number of genes modulated in common between the 2 drugs was low (6\%-22\%). For example, in A549 cells, AZA $(3 \mu \mathrm{M})$ and DAC $(3 \mu \mathrm{M})$ commonly upregulated 66 genes, while AZA uniquely upregulated 636 genes and DAC uniquely upregulated 413 genes (Table 2).

Functional groupings of the modulated genes were determined using Gene Ontology classifications in NextBio. Different biogroups were regulated by each drug. The top 200 biogroups most significantly regulated by each drug (at $3 \mu \mathrm{M}$ ) are shown in Supporting Information Tables 2-5. In H1299 cells, AZA treatment caused a general downregulation of genes within the "cell cycle", "metabolic process", and "biosynthetic process" biogroups. DAC treatment of H1299 cells caused a general upregulation of genes within the "cell differentiation" biogroup. In A549 cells, AZA treatment 
A
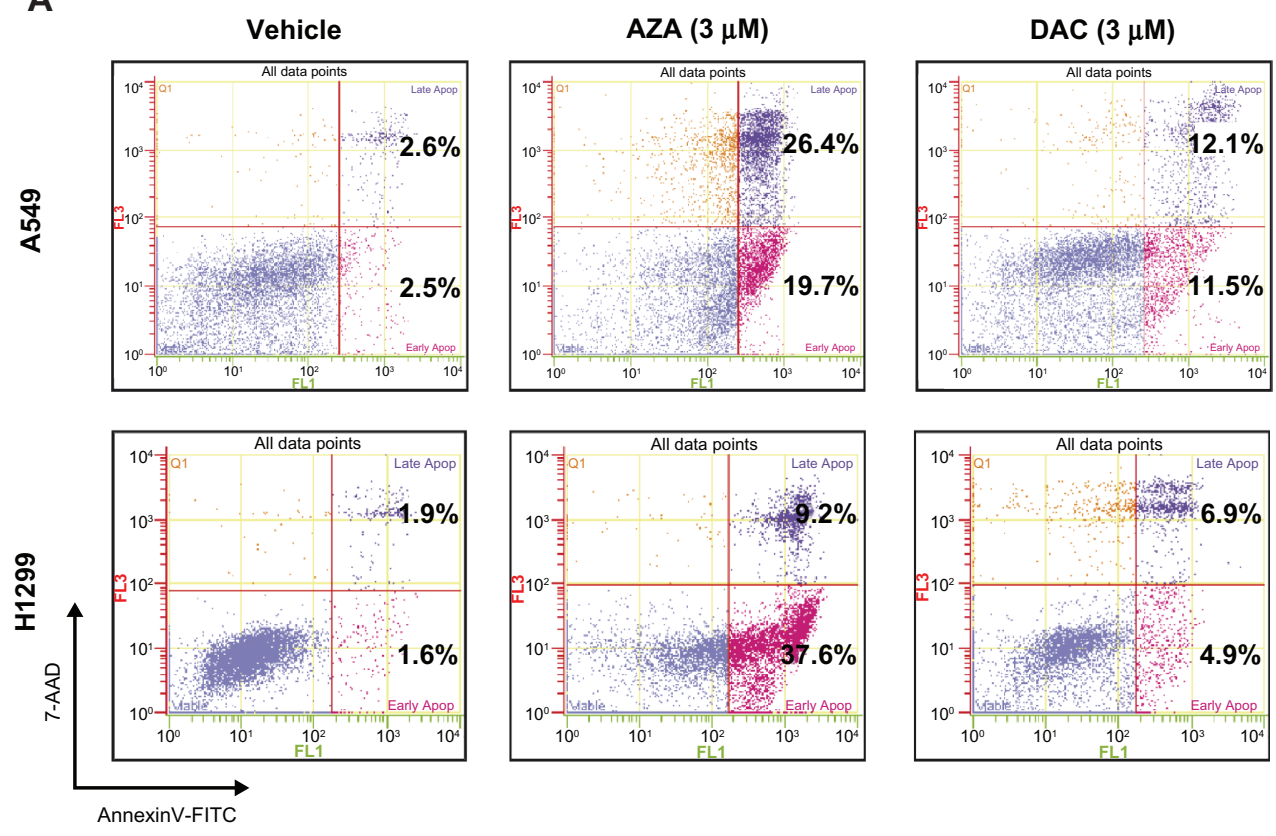

B
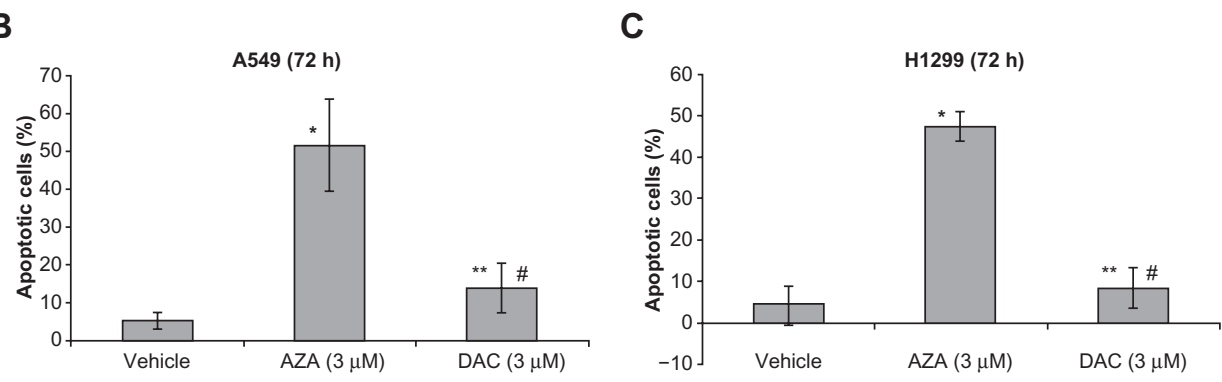

Figure 6 AZA, but not DAC, strongly induces apoptosis in NSCLC cell lines. A549 and HI 299 cells were treated with AZA or DAC ( $3 \mu$ M) for 72 hours, and staining for AnnexinV-FITC (x-axis) and 7-AAD (y-axis) was detected by flow cytometry. A) The percentages of early apoptotic cells and late apoptotic cells are represented in the lower right and upper right quadrants, respectively. Representative data of 4 independent experiments are shown. B) Percentage (mean \pm SD; $n=4)$ of apoptotic (early and late) cells with AZA or DAC treatment of A549 cells. *P $<0.00$ I versus "vehicle". **P $=0.328$ versus "vehicle". ${ }^{*} P<0.00 \mathrm{I}$ versus "AZA ( $\left.3 \mu \mathrm{M}\right)$ ". C) Percentage (mean $\pm S D ; n=4$ ) of apoptotic (early and late) cells with AZA or DAC treatment of HI 299 cells. *P $<0.00$ I versus "vehicle". $* * P=0.442$ versus "vehicle". $\# P<0.00$ I versus "AZA (3 $\mu \mathrm{M})$ ".

Abbreviations: AZA, azacitidine; DAC, decitabine; NSCLC, non-small cell lung cancer.

caused downregulation of genes involved in extracellular matrix, while DAC treatment caused downregulation of genes involved in cell cycle. Aside from the regulation of genes related to extracellular matrix, these results are similar to the gene expression data from AML cell lines treated with AZA and DAC. ${ }^{25}$ Interestingly, AZA treatment of A549 and H1299 cells caused a general upregulation of genes within the "response to DNA damage stimulus" and "DNA repair" biogroups (Figure 9, Supporting Information Tables 2 and 4). These results are consistent with the induction of the dsDNA damage marker (histone-H2AX(ser139) phosphorylation) by AZA in these cells (Figure 5). On the contrary, DAC treatment caused a general downregulation of genes within these biogroups in A549 cells (Figure 9, Supporting Information Table 3 ), and DAC did not significantly modulate these biogroups in H1299 cells (Supporting Information Table 5). Collectively, these results indicate that AZA and DAC regulate different cellular pathways.

\section{Discussion}

In this study, we revealed differential effects of AZA and DAC on cell viability in a panel of NSCLC cell lines, with AZA inducing greater cellular toxicity and markers of apoptosis (PARP cleavage and AnnexinV staining) in comparison to DAC. Furthermore, AZA induced phosphorylation of histone-H2AX(ser139), a marker of dsDNA damage, while DAC had no, or delayed, effect on this endpoint. The striking differences in the response of NSCLC cell lines to these structurally similar cytidine nucleoside analogs further support emerging evidence that the common perception of these agents as mechanistically interchangeable DNA hypomethylating agents should be reconsidered. ${ }^{25,26}$ 


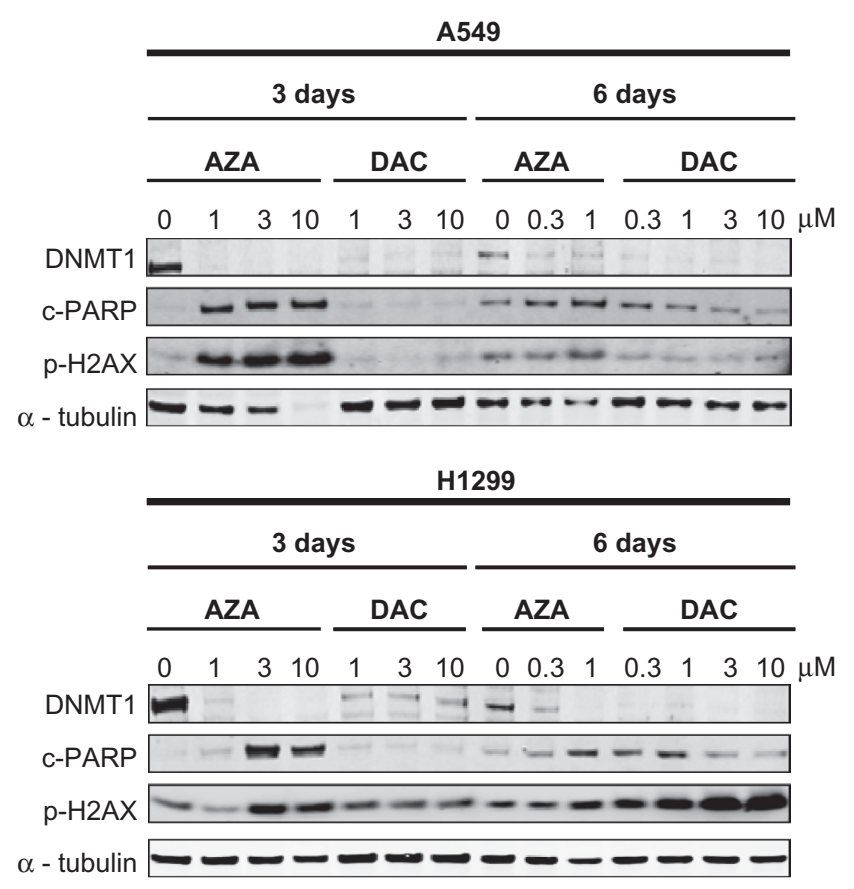

Figure 7 DAC-treated $\mathrm{H} 1299$ cells show delayed DNA damage response. A549 and $\mathrm{HI} 299$ cells were treated with AZA or DAC $(0-10 \mu \mathrm{M})$ for 3 and 6 days, and Western blotting of cell extracts was used to detect DNMTI, cleaved-PARP, and phospho-histone-H2AX(ser 139). Alpha-tubulin was used as a loading control. Abbreviations: AZA, azacitidine; DAC, decitabine; DNMTI, DNA methyltransferase I.

Other recent publications also provide data which differentiate AZA from DAC. For example, an in vitro study evaluating the response of a panel of human cancer cell lines to AZA and DAC showed no correlation in the $\mathrm{EC}_{50}$ values of the drugs. ${ }^{24}$ Another study comparing AZA and DAC activity in the Kasumi-1 AML cell line showed that these drugs had distinct and largely non-overlapping effects on gene expression profiles. ${ }^{26}$ We have recently demonstrated that AZA and DAC have different effects on cell viability, protein synthesis, cell cycle, and gene expression in AML cell lines. ${ }^{25}$ Similar to the findings in AML cell lines, ${ }^{25,26}$ we now demonstrate notable differences between AZA and DAC effects on NSCLC cell lines.

Despite the differences in the activities of AZA and DAC on cytotoxicity and induction of dsDNA damage, both AZA and DAC were active in modulating the DNAmediated markers of DNMT1 protein depletion and LINE-1 hypomethylation. While DNA methylation undeniably contributes to cancer development and progression, ${ }^{27}$ it is not clear that the anticancer effects of cytidine azanucleoside analogs are solely driven by their DNA hypomethylating activity. Findings from several clinical studies suggest that DNA hypomethylation may not correlate with clinical response. For example, a study found that DNMT depletion caused by DAC treatment did not necessarily result in clinical response. ${ }^{28}$ Another clinical trial demonstrated that DAC-induced LINE-1 hypomethylation tended to be greater in patients who did not respond to therapy than in patients who did respond. ${ }^{29}$ Stresemann et al showed that a subset of patients who responded to AZA treatment did not display detectable DNA hypomethylation. ${ }^{30}$ These results suggest that mechanisms in addition to, or other than, DNA hypomethylation may be critical for the anticancer effects of these drugs.

DAC's potent activity on DNA-mediated markers (DNMT1 depletion and DNA hypomethylation) demonstrates that the lack of cytotoxic activity with DAC was not due to a lack of cellular uptake, drug phosphorylation, and DNA incorporation. It is unclear why DAC does not induce dsDNA damage, despite depleting DNMT1 protein and hypomethylating DNA in the NSCLC cell lines tested. The lack of DAC effects on dsDNA damage and on cytotoxicity is consistent with mounting evidence suggesting that DNA damage may be important for the antitumor effects observed with nucleoside analogs. ${ }^{31-34}$ Published data surrounding DAC-induced DNA damage are mixed. In HeLa and HCT116 cells, DAC induced histone-H2AX(ser139) phosphorylation in a DNMT1-dependent and ataxiatelangiectasia-mutated (ATM)-dependent manner; ${ }^{34}$ however, other researchers found that DAC induced DNA single-strand breaks, but not DNA double-strand breaks (DSBs) ${ }^{35-37}$ Our results suggest that AZA induces DSBs in NSCLC cell lines, coincident with its induction of apoptosis (Figure 5). DAC did not induce as much DSBs and cell death as AZA in A549 cells. Thus, DSBs may correlate with tumor cell death. Dose and schedule will influence mechanism of action, so the potential for cumulative effects of each drug given at low doses or extended schedules should be tested. Furthermore, potential activities of AZA and DAC on cancer stem cell viability and/or differentiation were not tested here.

In summary, we found that AZA and DAC differentially affected the viability of NSCLC cell lines. While AZA and DAC similarly caused DNMT1 depletion and DNA hypomethylation, the drugs differed in their effects on DNA damage, apoptosis, cell cycle, and gene expression. Perhaps a key difference is that AZA can be incorporated into both RNA and DNA, while DAC is only incorporated into DNA. ${ }^{25,38-41}$ The functional consequences of AZA incorporation into RNA can include (1) alterations in the synthesis and processing of various species of RNA, (2) inhibition of transcription, and (3) disruption of protein 


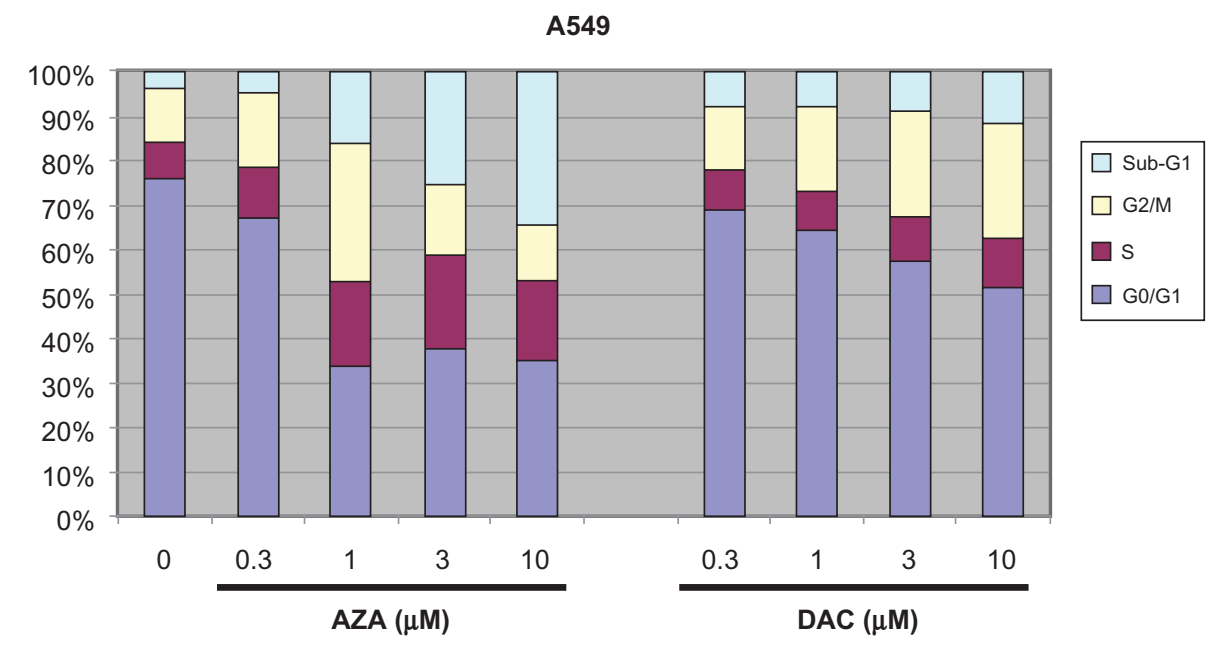

H1299

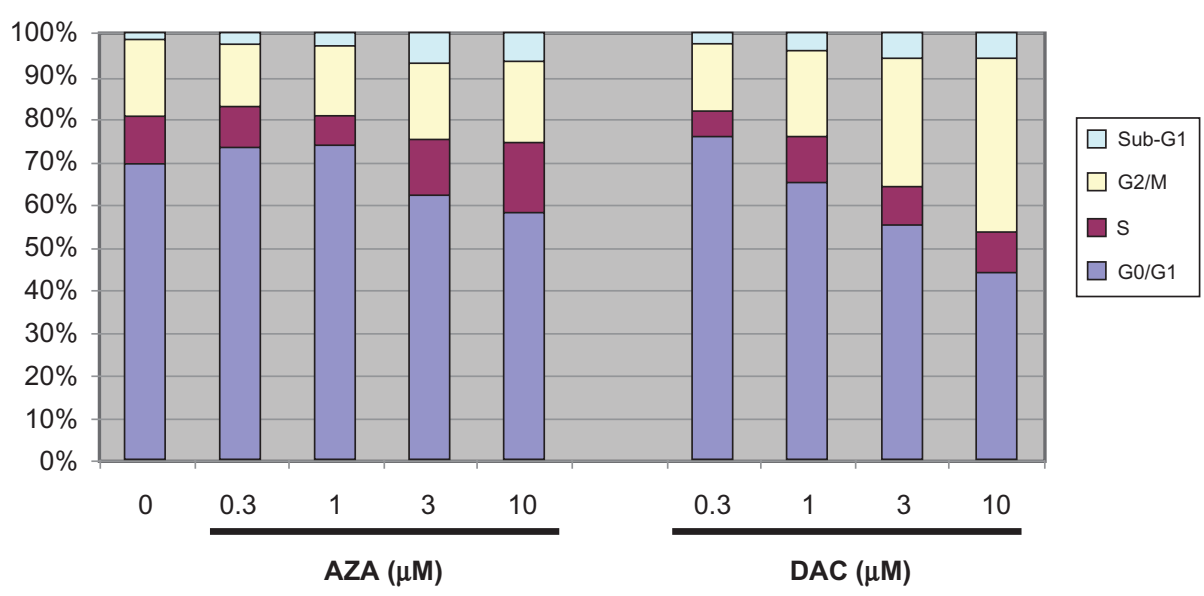

Figure 8 AZA increases the sub-GI population of cells, while DAC increases the G2/M population. A549 and HI299 cells were stained with NIM-DAPI after 72 hours of treatment with AZA or DAC at $0,0.3, \mathrm{I}, 3$, and $10 \mu \mathrm{M}$. The percentage of cells in sub-GI, G2/M, S, and G0/GI was quantified by flow cytometry. Representative data of 3 independent experiments are shown.

Abbreviations: AZA, azacitidine; DAC, decitabine.

synthesis. ${ }^{25,38,42-45}$ The in vitro anticancer activity of AZA in NSCLC models warrants its evaluation in the clinic. It will be important to consider the multiple mechanisms of AZA activity when selecting therapies for use in combination.

\section{Materials and methods}

\section{Cell culture and drug treatments}

NSCLC cell lines (H460, H1299, A549, and H1975) were purchased from American Type Culture Collection (ATCC, Manassas, VA). The H23 NSCLC cell line

Table 2 Number of genes regulated by AZA and/or DAC

\begin{tabular}{|c|c|c|c|c|c|c|c|}
\hline \multirow[t]{2}{*}{ Cell line } & \multirow{2}{*}{$\begin{array}{l}\text { [Drug] } \\
(\mu \mathrm{M})\end{array}$} & \multicolumn{3}{|c|}{ Upregulated genes } & \multicolumn{3}{|c|}{ Downregulated genes } \\
\hline & & $\begin{array}{l}\text { AZA-specific } \\
\text { genes }\end{array}$ & $\begin{array}{l}\text { Genes } \\
\text { in common }\end{array}$ & $\begin{array}{l}\text { DAC-specific } \\
\text { genes }\end{array}$ & $\begin{array}{l}\text { AZA-specific } \\
\text { genes }\end{array}$ & $\begin{array}{l}\text { Genes } \\
\text { in common }\end{array}$ & $\begin{array}{l}\text { DAC-specific } \\
\text { genes }\end{array}$ \\
\hline \multirow[t]{3}{*}{ A549 } & 0.3 & 16 & 17 & 139 & 14 & 11 & 55 \\
\hline & 1.0 & 279 & 45 & 261 & 273 & 30 & 111 \\
\hline & 3.0 & 636 & 66 & 413 & 560 & 55 & 239 \\
\hline \multirow[t]{3}{*}{ HI299 } & 0.3 & 10 & 55 & 214 & 33 & 45 & 121 \\
\hline & 1.0 & 435 & 135 & 238 & 393 & 107 & 170 \\
\hline & 3.0 & 1368 & 173 & 303 & 991 & 153 & 257 \\
\hline
\end{tabular}

Notes: A549 and HI299 cells were treated with AZA or DAC (0-3.0 $\mu \mathrm{M})$ for 48 hours, and RNA was isolated for evaluation of gene expression using Affymetrix human UI33A 2.0 gene chipset. The table shows the number of genes regulated by AZA and DAC at different drug concentrations. Duplicate samples of each were averaged and compared with untreated samples. A fold change of $\geq 1.7$ in gene expression was considered as regulated.

Abbreviations: AZA, azacitidine; DAC, decitabine. 


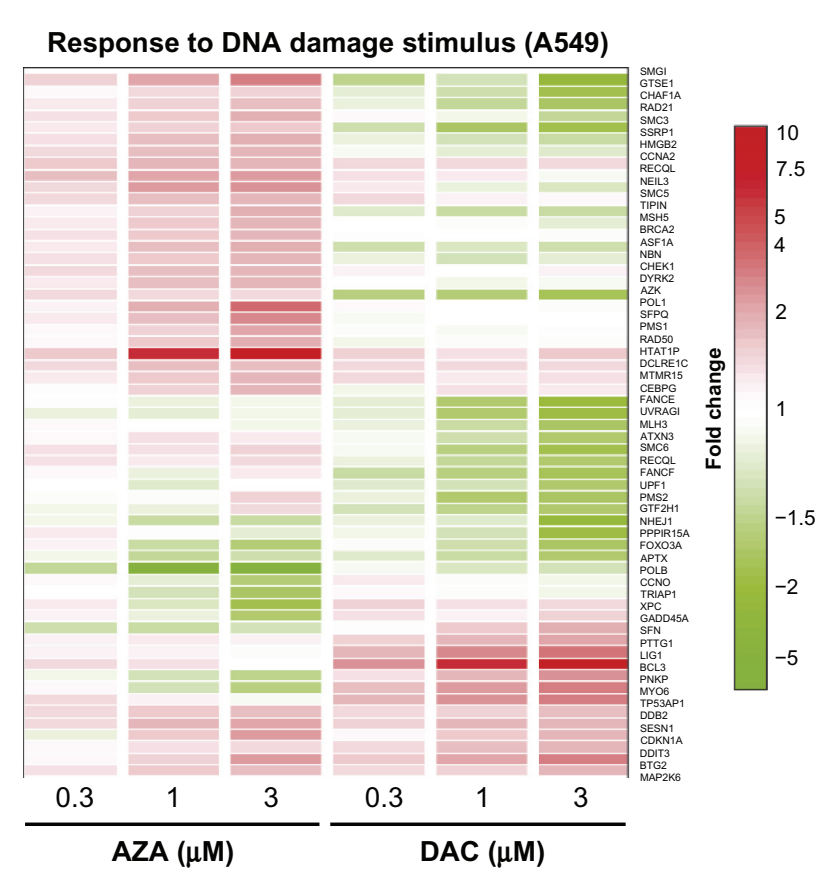

Figure 9 AZA upregulates, while DAC downregulates, genes important in the response to DNA damage stimulus. Gene expression profiling was performed in A549 cells after 48 hours of treatment with AZA or DAC at $0,0.3, I$, and $3 \mu \mathrm{M}$. NextBio (http://www.nextbio.com/) was used to identify regulated Gene Ontology biogroups from lists of regulated genes. The genes displayed represent all genes within the "response to DNA damage stimulus" biogroup that were modulated I.7fold or greater by AZA or DAC.

Abbreviations: AZA, azacitidine; DAC, decitabine.

was obtained from the National Cancer Institute (NCI) (Bethesda, MD). Cell lines were cultured in their respective media, as recommended by ATCC and NCI. AZA was manufactured at Aptuit (Greenwich, CT) for Celgene Corporation, while DAC was purchased from SigmaAldrich (St Louis, MO). In all experiments, cells were seeded 24 hours before drug treatment and incubated at $37^{\circ} \mathrm{C}$ and $5 \% \mathrm{CO}_{2}$. For cell viability assays, $\mathrm{H} 460, \mathrm{H} 1299$, A549, H23, and H1975 cells were seeded in triplicate at $1 \times 10^{3}, 1 \times 10^{3}, 1 \times 10^{3}, 4 \times 10^{3}$, and $4 \times 10^{3}$ cells per well, respectively, in 96-well plates using $200 \mu \mathrm{L}$ of medium per well. As the half-lives of AZA and DAC in cell culture are short ( $\sim-12$ hours) (data not shown), fresh drug was added every 24 hours by replacing medium with drug-containing medium. For all other assays, cells were seeded at $0.6-1.2 \times 10^{5}$ cells per well, in 6-well plates, using $4 \mathrm{~mL}$ of medium per well, with fresh drug added directly to the medium every 24 hours. At this seeding density, cells are $30 \%-40 \%$ confluent at the start of drug treatments. The concentrations of AZA and DAC used in these experiments are similar to the maximum concentrations (Cmax) achieved in human plasma at clinically used dosages and schedules of administration (3-11 $\mu \mathrm{M}$ AZA and $0.3-1.6 \mu \mathrm{M} \mathrm{DAC}) .{ }^{28,46,47}$

\section{Cell viability}

Cell viability was assessed 72 hours after the initial drug treatment, using the CyQUANT assay (Life Technologies Corporation, Carlsbad, CA). Fluorescence was measured with a spectrophotometer (Molecular Devices, Sunnyvale, $\mathrm{CA}$ ), and $\mathrm{EC}_{50}$ values were calculated from three independent experiments using Prism version 5.01 (GraphPad Software, Inc., La Jolla, CA).

\section{Western analysis}

For Western analyses of protein levels, cells were washed with phosphate-buffered saline (PBS) and lysed with radio immuno precipitation assay (RIPA) buffer (Cell Signaling Technology, Inc., Danvers, MA) supplemented with $350 \mathrm{mM} \mathrm{NaCl}$ and $0.1 \%$ sodium dodecyl sulfate (SDS). Cell lysates were sonicated with two 5 -second bursts under low amplitude (20\%) using the Digital Sonic Dismembrator (ThermoFisher Scientific, Inc., Waltham, MA). Proteins were separated on $4 \%-12 \%$ Bis-Tris NuPAGE gels (Life Technologies Corporation) and transferred to nitrocellulose membranes. DNMT1, phospho-histone-H2AX(ser139), total histone-H2AX, cleaved-PARP, and alpha-tubulin were detected using the Li-Cor Odyssey imaging system (Li-Cor Biotechnology, Lincoln, NE), following incubation with the appropriate primary and secondary antibodies. The phospho-histone-H2AX(ser139) and cleaved-PARP antibodies were obtained from Cell Signaling Technology, Inc. The total histone-H2AX (C-20) antibody was purchased from Santa Cruz Biotechnology, Inc. (Santa Cruz, CA). The alpha-tubulin and DNMT1 antibodies were purchased from EMD Chemicals, Inc. (Gibbstown, NJ) and Abcam, Inc. (Cambridge, MA), respectively. The goat anti-Rabbit IRDye 680 , goat anti-Mouse IRDye $800 \mathrm{CW}$, and donkey anti-Goat IRDye $800 \mathrm{CW}$ secondary antibodies were obtained from Li-Cor Biotechnology.

\section{DNA methylation analysis}

Genomic DNA was purified from cells using the DNeasy Blood and Tissue Kit (Qiagen, Valencia, CA), according to the manufacturer's instructions. DNA yield was quantitated with a NanoDrop 8000 spectrophotometer (ThermoFisher Scientific, Inc.). Genomic DNA (1 $\mu \mathrm{g} / \mathrm{sample})$ was submitted to EpigenDx (Worcester, MA) for bisulfite conversion and pyrosequencing of LINE-1 elements. Briefly, $1 \mu \mathrm{g}$ of DNA was bisulfite treated using the Zymo DNA Methylation Kit (Zymo Research, Orange, CA) and eluted in $10 \mu \mathrm{L}$ volume. DNA eluate $(1 \mu \mathrm{L})$ was used for polymerase chain reaction (PCR) with biotinylated primers to the LINE-1 locus, converting the PCR product to single-stranded DNA 
templates. PCR products (each $10 \mu \mathrm{L}$ ) were sequenced by the Pyrosequencing PSQ96 HS System (Biotage AB), following the manufacturer's instructions (Biotage, Kungsgatan, Sweden). The methylation status of each locus was analyzed individually as a T/C SNP using QCpG software (Biotage). Percentage LINE-1 methylation represents the average percentage methylation of $4 \mathrm{CpG}$ sites in duplicate samples. EpigenDx provided 3 controls for the LINE-1 methylation assay: (1) low methylated DNA control, which is human genomic DNA that has been chemically and enzymatically treated to remove the methyl groups; (2) high methylated DNA control, which is human genomic DNA that has been methylated in vitro; and (3) 50/50 mix control, which is an equal mixture of the low methylated DNA and high methylated DNA controls. The percentages of LINE-1 methylation for the low methylated DNA control, the 50/50 mix control, and the high methylated DNA control were $25.8 \pm 8.1,56.2 \pm 4.6$, and $86.3 \pm 6.5$, respectively (data not shown).

\section{Flow cytometry}

For cell cycle distribution, cells were stained with the NIM-DAPI reagent (Beckman Coulter, Inc., Fullerton, CA). For measurement of early- and late-apoptotic cell populations, cells were stained with AnnexinV-FITC and 7-AAD reagents (Beckman Coulter, Inc.). Samples were processed according to manufacturer's instructions and analyzed on a Cell Lab Quanta MPL flow cytometer (Beckman Coulter, Inc.). The effects of treatment were compared using one-way ANOVA, followed by single step method for adjusting $P$-values in multiple testing with the bioconductor package multcomp. ${ }^{48}$

\section{Gene expression analysis}

Cells were lysed using the TRIzol reagent (Life Technologies Corporation), and total RNA was isolated using the miRNeasy kit (Qiagen). Double-stranded cDNA and biotinlabeled cRNA were synthesized using $100 \mathrm{ng}$ of total RNA with Ambion's MessageAmp Premier RNA Amplification Kit (ABI, Foster City, CA). Biotin-labeled cRNA (10 $\mu \mathrm{g})$ was fragmented and hybridized to each human U133A 2.0 genechip (Affymetrix, Santa Clara, CA). The GC-RMA algorithm was used for normalization, and all analyses were done using GeneSpring 7.3 (Agilent, Santa Clara, CA). Averaged signals from biological duplicate samples were used to determine fold change (treated versus untreated), with an absolute fold change of $\geq 1.7$ defining regulated genes. NextBio (http://www.nextbio.com/) was used to identify regulated gene ontology biogroups from lists of regulated genes. The top 200 biogroups are those with the lowest $P$-values calculated within NextBio.

\section{Acknowledgments}

We would like to acknowledge Sharon Aukerman, Victoria Sung, and Sharianne Louie for critical review of the manuscript. We thank Gina Fusaro and Marianna Shafarenko for their assistance with manuscript editing. We also thank Xiaoyue Zhao for statistical analyses. Vidaza is a marketed product with azacitidine as the active pharmaceutical ingredient. Dacogen is a marketed product with decitabine as the active pharmaceutical ingredient.

\section{Disclosure}

ANN, PWH, NR, AL-M, HB, CH, and KJM are employees of Celgene and as such own stock in the company.

\section{References}

1. Silverman LR, Demakos EP, Peterson BL, et al. Randomized controlled trial of azacitidine in patients with the myelodysplastic syndrome: a study of the cancer and leukemia group B. J Clin Oncol. 2002;20(10):2429-2440.

2. Kantarjian H, Issa JP, Rosenfeld CS, et al. Decitabine improves patient outcomes in myelodysplastic syndromes: results of a phase III randomized study. Cancer. 2006;106(8):1794-1803.

3. Santi DV, Norment A, Garrett CE. Covalent bond formation between a DNA-cytosine methyltransferase and DNA containing 5-azacytosine. Proc Natl Acad Sci U S A. 1984;81(22):6993-6997.

4. Weisenberger DJ, Velicescu M, Cheng JC, Gonzales FA, Liang G, Jones PA. Role of the DNA methyltransferase variant DNMT3b3 in DNA methylation. Mol Cancer Res. 2004;2(1):62-72.

5. Jones PA, Taylor SM. Cellular differentiation, cytidine analogs and DNA methylation. Cell. 1980;20(1):85-93.

6. HaafT. The effects of 5-azacytidine and 5-azadeoxycytidine on chromosome structure and function: implications for methylation-associated cellular processes. Pharmacol Ther. 1995;65(1):19-46.

7. Chuang JC, Yoo CB, Kwan JM, et al. Comparison of biological effects of non-nucleoside DNA methylation inhibitors versus 5aza-2'-deoxycytidine. Mol Cancer Ther. 2005;4(10):1515-1520.

8. Stresemann C, Brueckner B, Musch T, Stopper H, Lyko F. Functional diversity of DNA methyltransferase inhibitors in human cancer cell lines. Cancer Res. 2006;66(5):2794-2800.

9. Yoo CB, Jones PA. Epigenetic therapy of cancer: past, present and future. Nat Rev Drug Discov. 2006;5(2):37-50.

10. Esteller M. Profiling aberrant DNA methylation in hematologic neoplasms: a view from the tip of the iceberg. Clin Immunol. 2003; 109(1):80-88.

11. Esteller M. CpG island hypermethylation and tumor suppressor genes: a booming present, a brighter future. Oncogene. 2002;21(35): $5427-5440$

12. Burbee DG, Forgacs E, Zöchbauer-Müller S, et al. Epigenetic inactivation of RASSF1A in lung and breast cancers and malignant phenotype suppression. J Natl Cancer Inst. 2001;93(9):691-699.

13. Brabender J, Usadel H, Danenberg KD, et al. Adenomatous polyposis coli gene promoter hypermethylation in non-small cell lung cancer is associated with survival. Oncogene, 2001;20(27):3528-3532.

14. Kim DH, Nelson HH, Wiencke JK, et al. p16(INK4a) and histology-specific methylation of $\mathrm{CpG}$ islands by exposure to tobacco smoke in non-small cell lung cancer. Cancer Res. 2001;61(8): 3419-3424. 
15. Maruyama R, Sugio K, Yoshino I, Maehara Y, Gazdar AF. Hypermethylation of FHIT as a prognostic marker in nonsmall cell lung carcinoma. Cancer. 2004;100(7):1472-1477.

16. Schrump DS, Fischette MR, Nguyen DM, et al. Phase I study of decitabine-mediated gene expression in patients with cancers involving the lungs, esophagus, or pleura. Clin Cancer Res. 2006;12(19): 5777-5785.

17. Samlowski WE, Leachman SA, Wade M, et al. Evaluation of a 7-day continuous intravenous infusion of decitabine: inhibition of promoterspecific and global genomic DNA methylation. J Clin Oncol. 2005; 23(17):3897-3905.

18. Weiss AJ, Metter GE, Nealon TF, et al. Phase II study of 5-azacytidine in solid tumors. Cancer Treat Rep. 1977;61(1):55-58.

19. Lin J, Gilbert J, Rudek MA, et al. A phase I dose-finding study of 5azacytidine in combination with sodium phenylbutyrate in patients with refractory solid tumors. Clin Cancer Res. 2009;15(19):6241-6249.

20. Bepler G, Kusmartseva I, Sharma S, et al. RRM1 modulated in vitro and in vivo efficacy of gemcitabine and platinum in non-small cell lung cancer. J Clin Oncol. 2006;24(29):4731-4737.

21. Oguri T, Achiwa H, Sato S, et al. The determinants of sensitivity and acquired resistance to gemcitabine differ in non-small cell lung cancer: a role of ABCC5 in gemcitabine sensitivity. Mol Cancer Ther. 2006; 5(7):1800-1806.

22. Voortman J, Checinska A, Giaccone G, Rodriguez JA, Kruyt FA. Bortezomib, but not cisplatin, induces mitochondria-dependent apoptosis accompanied by up-regulation of noxa in the non-small cell lung cancer cell line NCI-H460. Mol Cancer Ther. 2007;6(3):1046-1053.

23. Qin T, Youssef EM, Jelinek J, et al. Effect of cytarabine and decitabine in combination in human leukemic cell lines. Clin Cancer Res. 2007;13(14):4225-4232.

24. Qin T, Jelinek J, Si J, Shu J, Issa JP. Mechanisms of resistance to 5-aza-2'-deoxycytidine in human cancer cell lines. Blood. 2009; 113(3):659-667

25. Hollenbach PW, Nguyen AN, Brady H, et al. A comparison of azacitidine and decitabine activities in acute myeloid leukemia cell lines. PLoS One. 2010;5(2):e9001.

26. Flotho C, Claus R, Batz C, et al. The DNA methyltransferase inhibitors azacitidine, decitabine and zebularine exert differential effects on cancer gene expression in acute myeloid leukemia cells. Leukemia. 2009;23(6):1019-1028.

27. Sadikovic B, Al-Romaih K, Squire JA, Zielenska M. Cause and consequences of genetic and epigenetic alterations in human cancer. Curr Genomics. 2008;9(6):394-408

28. Blum W, Klisovic RB, Hackanson B, et al. Phase I study of decitabine alone or in combination with valproic acid in acute myeloid leukemia. $J$ Clin Oncol. 2007;25(25):3884-3891.

29. Oki Y, Kantarjian HM, Gharibyan V, et al. Phase II study of low-dose decitabine in combination with imatinib mesylate in patients with accelerated or myeloid blastic phase of chronic myelogenous leukemia. Cancer. 2007;109(5):899-906.

30. Stresemann C, Bokelmann I, Mahlknecht U, Lyko F. Azacytidine causes complex DNA methylation responses in myeloid leukemia. Mol Cancer Ther. 2008;7(9):2998-3005

31. Karpf AR, Moore BC, Ririe TO, Jones DA. Activation of the p53 DNA damage response pathway after inhibition of DNA methyltransferase by 5-aza-2'-deoxycytidine. Mol Pharmacol. 2001;59(4):751-757.
32. Kiziltepe T, Hideshima T, Catley L, et al. 5-Azacytidine, a DNA methyltransferase inhibitor, induces ATR-mediated DNA double-strand break responses, apoptosis, and synergistic cytotoxicity with doxorubicin and bortezomib against multiple myeloma cells. $\mathrm{Mol}$ Cancer Ther. 2007;6(6):1718-1727.

33. Jiemjit A, Fandy TE, Carraway H, et al. p21(WAF1/CIP1) induction by 5 -azacytosine nucleosides requires DNA damage. Oncogene. 2008;27(25):3615-3623.

34. Palii SS, van Emburgh BO, Sankpal UT, Brown KD, Robertson KD. DNA methylation inhibitor 5-Aza-2'-deoxycytidine induces reversible genome-wide DNA damage that is distinctly influenced by DNA methyltransferases 1 and 3B. Mol Cell Biol. 2008;28(2):752-771.

35. D'Incalci M, Covey JM, Zaharko DS, Kohn KW. DNA alkali-labile sites induced by incorporation of 5-aza-2'-deoxycytidine into DNA of mouse leukemia L1210 cells. Cancer Res. 1985;45(7):3197-3202.

36. Covey JM, D'Incalci M, Tilchen EJ, Zaharko DS, Kohn KW. Differences in DNA damage produced by incorporation of 5-aza-2'-deoxycytidine or 5,6-dihydro-5-azacytidine into DNA of mammalian cells. Cancer Res. 1986;46(11):5511-5517.

37. Chai G, Li L, Zhou W, et al. HDAC inhibitors act with 5-aza2'-deoxycytidine to inhibit cell proliferation by suppressing removal of incorporated abases in lung cancer cells. PLoS One. 2008; 3(6):e2445.

38. Li LH, Olin EJ, Buskirk HH, Reineke LM. Cytotoxicity and mode of action of 5-azacytidine on L1210 leukemia. Cancer Res. 1970; 30(11):2760-2769.

39. Veselý J, Cihák A. Incorporation of a potent antileukemic agent, 5aza-2'-deoxycytidine, into DNA of cells from leukemic mice. Cancer Res. 1977;37(10):3684-3689.

40. Bouchard J, Momparler RL. Incorporation of 5-Aza-2'-deoxycytidine-5'triphosphate into DNA. Interactions with mammalian DNA polymerase alpha and DNA methylase. Mol Pharmacol. 1983;24(1):109-114.

41. Glazer RI, Knode MC. 1-beta-D-arabinosyl-5-azacytosine. Cytocidal activity and effects on the synthesis and methylation of DNA in human colon carcinoma cells. Mol Pharmacol. 1984;26(2):381-387.

42. Cihák A. Biological effects of 5-azacytidine in eukaryotes. Oncology. 1974;30(5):405-422.

43. Lu LJ, Randerath K. Effects of 5-azacytidine on transfer RNA methyltransferases. Cancer Res. 1979;39(3):940-949.

44. Cohen MB, Glazer RI. Cytotoxicity and the inhibition of ribosomal RNA processing in human colon carcinoma cells. Mol Pharmacol. 1985;27(2):308-313.

45. Glover AB, Leyland-Jones B. Biochemistry of azacitidine: a review. Cancer Treat Rep. 1987;71(10):959-964.

46. Marcucci G, Silverman L, Eller M, Lintz L, Beach CL. Bioavailability of azacitidine subcutaneous versus intravenous in patients with the myelodysplastic syndromes. J Clin Pharmacol. 2005;45(5):597-602.

47. Cashen AF, Shah AK, Todt L, Fisher N, DiPersio J. Pharmacokinetics of decitabine administered as a 3-h infusion to patients with acute myeloid leukemia (AML) or myelodysplastic syndrome (MDS). Cancer Chemother Pharmacol. 2008;61(5):759-766.

48. Hothorn T, Bretz F, Westfall P. Simultaneous inference in general parametric models. Biom J. 2008;50(3):346-363. 


\section{Supporting information figures and tables}
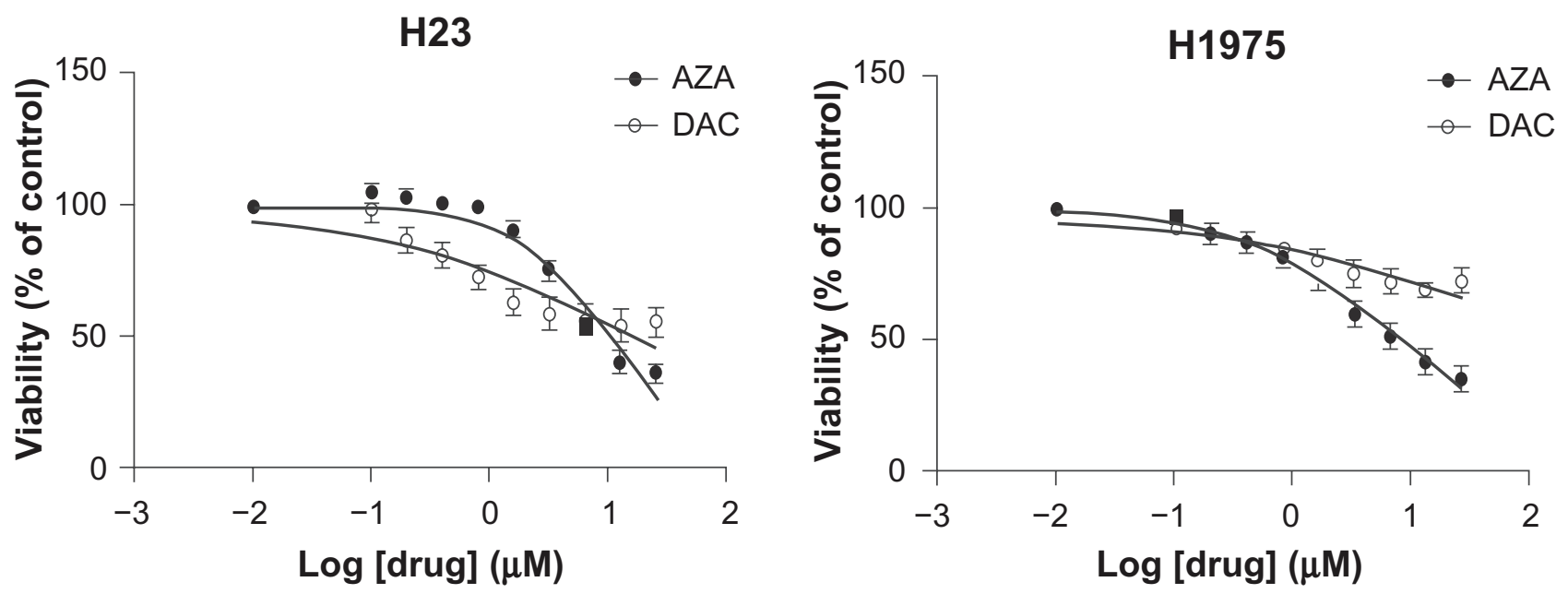

Figure SI Viability of $\mathrm{H} 23$ and HI975 cells was assessed after 72 hours of treatment with AZA or DAC (0-25 $\mu$ M). Error bars represent the standard error of mean of three independent experiments, with triplicate wells per experiment.

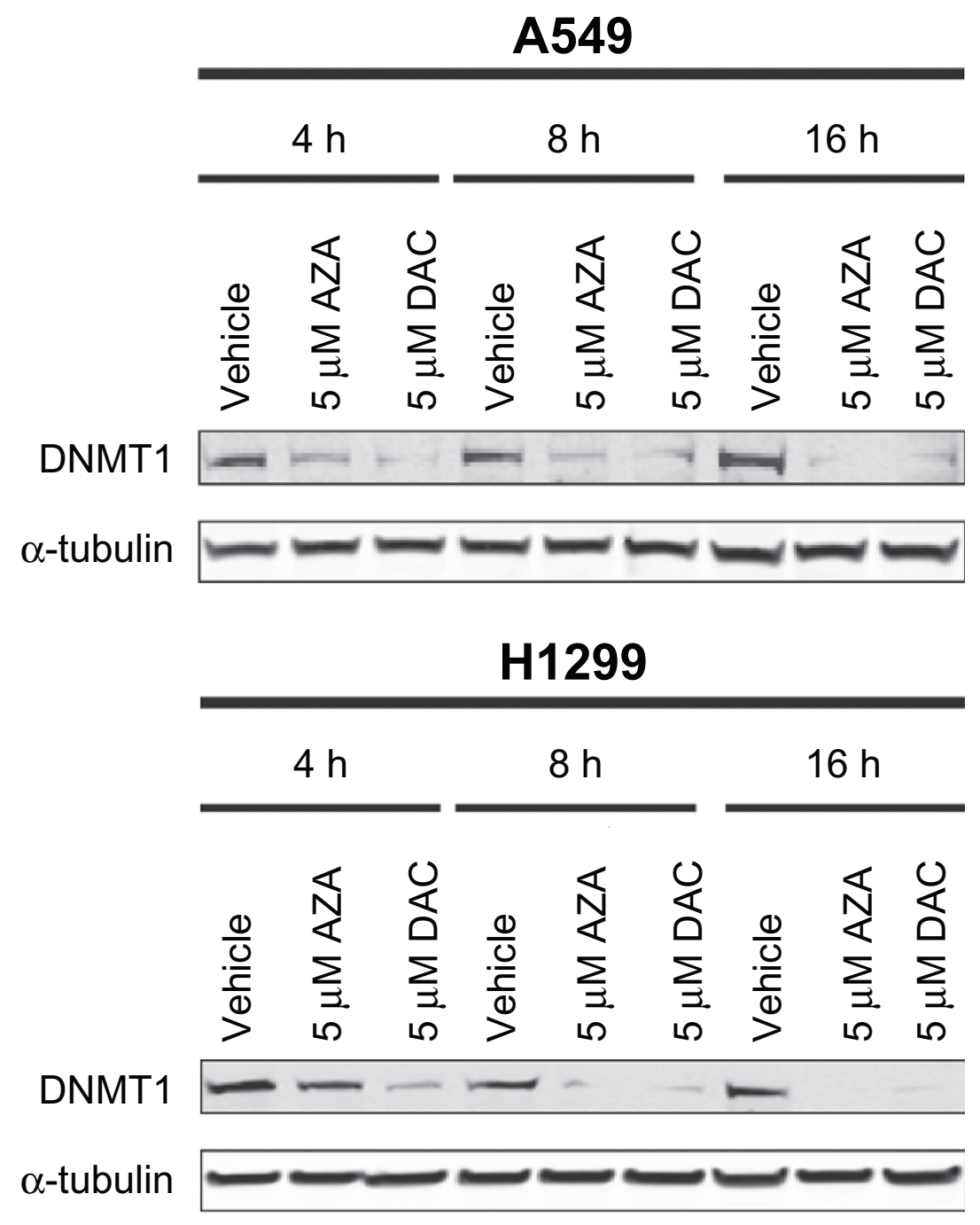

Figure S2 AZA and DAC cause DNMTI depletion in NSCLC cell lines. A549 and HI299 cells were treated with AZA or DAC (5 $\mu$ M) for 4, 8, or 16 hours and DNMTI protein was detected by Western blotting of cell extracts. Alpha-tubulin was used as a loading control. 

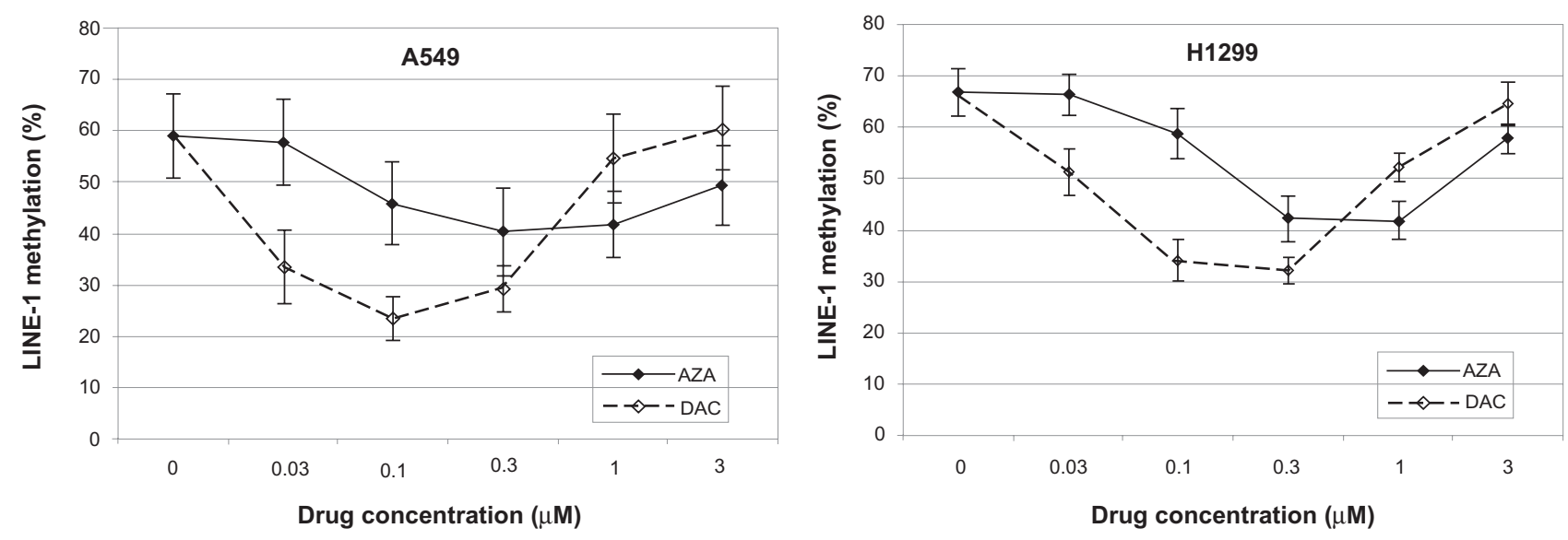

Figure S3 AZA and DAC reduce DNA methylation in A549 and HI 299 cells. LINE-I DNA methylation was assessed in A549 and HI 299 cells after 72 hours of treatment with AZA or DAC (0-3 $\mu \mathrm{M})$. Percentage LINE-I methylation represents the average percentage methylation of 4 CpG sites in duplicate samples, with error bars representing the standard deviation.
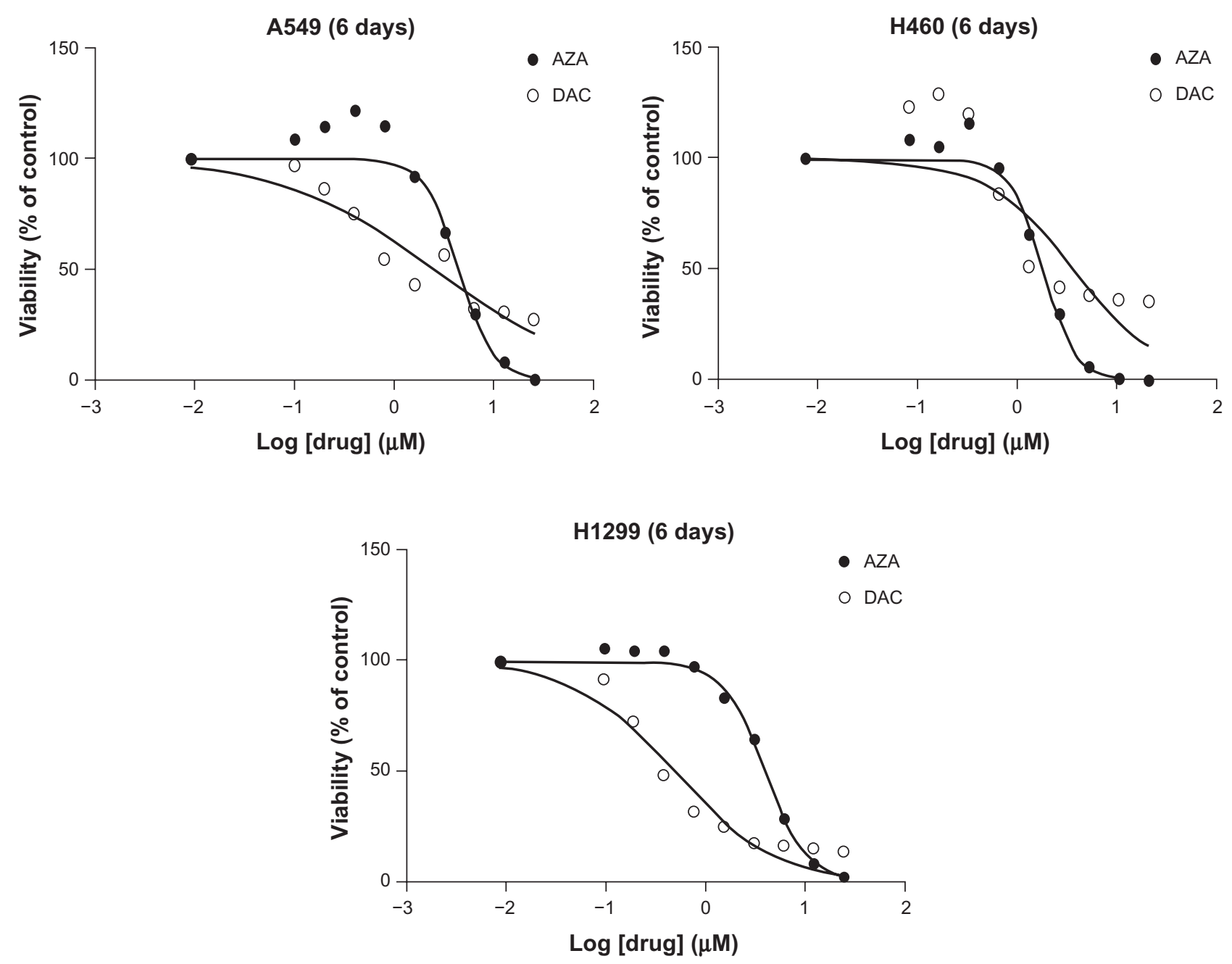

Figure S4 Viability of A549, H460, and HI299 cells was assessed after 6 days of treatment with AZA or DAC (0-25 $\mu \mathrm{M})$. 
Table SI EC $_{50}$ values for AZA and DAC on NSCLC cell viability (6 days)

\begin{tabular}{lll}
\hline & AZA EC $_{50}(\mu \mathrm{M})$ & DAC EC $_{50}(\mu \mathrm{M})$ \\
\hline A549 & 4.4 & 2.5 \\
H460 & 2.2 & 4.4 \\
HI299 & 4.1 & 0.5 \\
\hline
\end{tabular}

Abbreviations: AZA, azacitidine; DAC, decitabine; NSCLC, non-small cell lung cancer.

Table S2 Top 200 biogroups modulated by azacitidine (AZA) in A549 cells

\begin{tabular}{|c|c|c|}
\hline \multicolumn{3}{|c|}{ A549 cells treated with $3 \mu$ M AZA (48 hours) } \\
\hline Biogroup name & Direction & $P$ value \\
\hline Proteinaceous extracellular matrix & down & $3.40 \mathrm{E}-18$ \\
\hline Extracellular matrix & down & $4.70 \mathrm{E}-18$ \\
\hline Transcription & up & $2.50 \mathrm{E}-16$ \\
\hline Extracellular matrix structural constituent & down & $4.90 \mathrm{E}-16$ \\
\hline Glycosaminoglycan binding & down & $7.30 \mathrm{E}-15$ \\
\hline Polysaccharide binding & down & $9.60 \mathrm{E}-15$ \\
\hline Pattern binding & down & $2.80 \mathrm{E}-14$ \\
\hline Lipid biosynthetic process & down & $3.60 \mathrm{E}-14$ \\
\hline Fibrillar collagen & down & $1.60 \mathrm{E}-13$ \\
\hline Calcium ion binding & down & $2.20 \mathrm{E}-13$ \\
\hline Fibrinogen complex & down & $7.20 \mathrm{E}-13$ \\
\hline Humoral immune response & down & $8.90 \mathrm{E}-12$ \\
\hline Protein binding, bridging & down & $9.00 \mathrm{E}-12$ \\
\hline Collagen & down & I.70E-II \\
\hline Response to wounding & down & $6.00 \mathrm{E}-\mathrm{II}$ \\
\hline Response to external stimulus & down & $1.50 \mathrm{E}-10$ \\
\hline Platelet activation & down & $2.20 \mathrm{E}-10$ \\
\hline $\begin{array}{l}\text { Ligase activity, forming aminoacyl-tRNA } \\
\text { and related compounds }\end{array}$ & up & 3.30E-10 \\
\hline Ligase activity, forming carbon-oxygen bonds & up & $3.30 \mathrm{E}-10$ \\
\hline Response to nutrient & up & $3.70 \mathrm{E}-10$ \\
\hline Carbohydrate binding & down & $3.80 \mathrm{E}-10$ \\
\hline Basement membrane & down & I.00E-09 \\
\hline Lipid metabolic process & down & $2.20 \mathrm{E}-09$ \\
\hline Response to nutrient levels & up & $2.30 \mathrm{E}-09$ \\
\hline Steroid biosynthetic process & down & $2.30 \mathrm{E}-09$ \\
\hline Collagen binding & down & $2.40 \mathrm{E}-09$ \\
\hline Response to extracellular stimulus & up & $3.70 \mathrm{E}-09$ \\
\hline Inflammatory response & down & $7.80 \mathrm{E}-09$ \\
\hline Nucleoplasm & up & $8.70 \mathrm{E}-09$ \\
\hline Acute inflammatory response & down & I.30E-08 \\
\hline Response to stress & down & I.50E-08 \\
\hline Blood pressure regulation & down & I.50E-08 \\
\hline RNA binding & up & I.60E-08 \\
\hline Cell motility & down & $3.40 \mathrm{E}-08$ \\
\hline Localization of cell & down & $3.40 \mathrm{E}-08$ \\
\hline Epithelial cell differentiation & down & $4.70 \mathrm{E}-08$ \\
\hline tRNA binding & up & $4.80 \mathrm{E}-08$ \\
\hline Steroid metabolic process & down & $7.20 \mathrm{E}-08$ \\
\hline Endoplasmic reticulum & down & $8.00 \mathrm{E}-08$ \\
\hline Translation & up & I.30E-07 \\
\hline Fatty acid biosynthetic process & down & I.90E-07 \\
\hline Parturition & down & $2.50 \mathrm{E}-07$ \\
\hline Sterol metabolic process & down & $2.50 \mathrm{E}-07$ \\
\hline
\end{tabular}

(Continued)
Table S2 (Continued)

A549 cells treated with $3 \mu$ M AZA (48 hours)

\begin{tabular}{lll}
\hline Biogroup name & Direction & $P$ value \\
\hline Blood coagulation & down & $2.90 \mathrm{E}-07$ \\
Coagulation & down & $3.10 \mathrm{E}-07$ \\
Humoral immune response mediated by & down & $3.60 \mathrm{E}-07$ \\
circulating immunoglobulin & & \\
Hemostasis & down & $3.60 \mathrm{E}-07$ \\
Organic acid biosynthetic process & down & $4.40 \mathrm{E}-07$ \\
Regulation of body fluids & down & $6.70 \mathrm{E}-07$ \\
Wound healing & down & $6.90 \mathrm{E}-07$ \\
ER-Golgi intermediate compartment & down & $8.00 \mathrm{E}-07$ \\
Actin binding & down & $9.70 \mathrm{E}-07$ \\
Anion transport & down & $1.10 \mathrm{E}-06$ \\
Extracellular structure organization and & down & $1.10 \mathrm{E}-06$ \\
biogenesis & & \\
Transaminase activity & up & $1.10 \mathrm{E}-06$ \\
Complement activation & down & $1.20 \mathrm{E}-06$ \\
Extracellular matrix organization & down & $1.20 \mathrm{E}-06$ \\
and biogenesis & & \\
Calmodulin binding & down & $1.90 \mathrm{E}-06$ \\
Circulation & down & $1.90 \mathrm{E}-06$ \\
Female pregnancy & down & $2.50 \mathrm{E}-06$ \\
Cellular homeostasis & down & $2.60 \mathrm{E}-06$ \\
Morphogenesis of an epithelium & down & $2.70 \mathrm{E}-06$ \\
Cell proliferation & down & $3.10 \mathrm{E}-06$ \\
Alkene metabolic process & down & $3.10 \mathrm{E}-06$ \\
Ribosome biogenesis and assembly & up & $3.20 \mathrm{E}-06$ \\
Complement activation, classical pathway & down & $3.50 \mathrm{E}-06$ \\
Ribonucleoprotein complex biogenesis & up & $4.90 \mathrm{E}-06$ \\
and assembly & & \\
Sodumisotion & & $5.20 \mathrm{E}-06$
\end{tabular}

Sodium:potassium-exchanging down

5.20E-06

ATPase complex

Transferase activity, transferring nitrogenous up 5.80E-06 groups

Cell activation

6. $10 \mathrm{E}-06$

Endoplasmic reticulum lumen

Fatty acid metabolic process

Vesicular fraction

Cellular ion homeostasis

Cellular chemical homeostasis

Positive regulation of immune

system process

Positive regulation of immune response down I.IOE-05

Phosphoinositide binding

Activation of immune response

Positive regulation of multicellular

I. $40 \mathrm{E}-05$

I.50E-05

organismal process

Cofactor transporter activity

Soluble fraction

Enzyme inhibitor activity

Development of primary sexual

down

6.60E-06

6.90E-06

$8.20 \mathrm{E}-06$

I. IOE-05

I. IOE-05

down I.IOE-05

down

I.IOE-05

characteristics

NAD binding

Amine biosynthetic process

Cytoskeleton

down

down

I.60E-05

down

$\begin{array}{ll}\text { up } & \mathrm{I} .60 \mathrm{E}-05 \\ \text { up } & \mathrm{I} .70 \mathrm{E}-05\end{array}$

$\begin{array}{ll}\text { up } & 1.70 \mathrm{E}-05 \\ \text { down } & \mathrm{I} .70 \mathrm{E}-05\end{array}$

up I.80E-05

Lymphocyte mediated immunity

Receptor binding

Transcription corepressor activity

down

I.90E-05

up I.90E-05

down 2.20E-05

down 2.40E-05

down 2.50E-05

up

$2.50 \mathrm{E}-05$

(Continued) 
Table S2 (Continued)

\begin{tabular}{|c|c|c|}
\hline \multicolumn{3}{|c|}{ A549 cells treated with $3 \mu$ M AZA (48 hours) } \\
\hline Biogroup name & Direction & $P$ value \\
\hline Response to DNA damage stimulus & up & 2.60E-05 \\
\hline Cartilage development & down & 2.70E-05 \\
\hline SNARE complex & up & 2.80E-05 \\
\hline Gastrulation & up & $3.20 \mathrm{E}-05$ \\
\hline mRNA transport & up & $3.50 \mathrm{E}-05$ \\
\hline Epidermis development & down & 3.80E-05 \\
\hline Cell migration & down & 4.20E-05 \\
\hline Immune effector process & down & 4.20E-05 \\
\hline Response to hypoxia & down & 4.30E-05 \\
\hline Leukocyte mediated immunity & down & 4.50E-05 \\
\hline Adaptive immune response & down & 4.90E-05 \\
\hline $\begin{array}{l}\text { Adaptive immune response based on somatic } \\
\text { recombination of immune receptors built } \\
\text { from immunoglobulin superfamily domains }\end{array}$ & down & $4.90 \mathrm{E}-05$ \\
\hline Endopeptidase inhibitor activity & down & $5.00 \mathrm{E}-05$ \\
\hline Protease inhibitor activity & down & $5.00 \mathrm{E}-05$ \\
\hline $\begin{array}{l}\text { Oxidoreductase activity, acting on } \\
\text { heme group of donors }\end{array}$ & down & $5.30 \mathrm{E}-05$ \\
\hline $\begin{array}{l}\text { Oxidoreductase activity, acting on } \\
\text { heme group of donors, oxygen as acceptor }\end{array}$ & down & $5.30 \mathrm{E}-05$ \\
\hline Cytochrome-c oxidase activity & down & $5.30 \mathrm{E}-05$ \\
\hline Heme-copper terminal oxidase activity & down & $5.30 \mathrm{E}-05$ \\
\hline Germ cell migration & up & $6.00 \mathrm{E}-05$ \\
\hline Coenzyme binding & down & $6.20 \mathrm{E}-05$ \\
\hline Regulation of translation & up & $6.90 \mathrm{E}-05$ \\
\hline Cytokine biosynthetic process & up & 7.30E-05 \\
\hline Neurotransmitter:sodium symporter activity & up & 7.40E-05 \\
\hline Ectoderm development & down & 7.50E-05 \\
\hline Establishment of RNA localization & up & $8.00 \mathrm{E}-05$ \\
\hline RNA transport & up & 8.00E-05 \\
\hline Nucleic acid transport & up & 8.00E-05 \\
\hline Transcription factor binding & up & $8.30 \mathrm{E}-05$ \\
\hline Regulation of immune response & down & 8.50E-05 \\
\hline Regulation of immune system process & down & 8.50E-05 \\
\hline Ligase activity & up & $8.60 \mathrm{E}-05$ \\
\hline RNA localization & up & $9.10 \mathrm{E}-05$ \\
\hline Neurotransmitter transporter activity & up & $9.30 \mathrm{E}-05$ \\
\hline RNA export from nucleus & up & $9.80 \mathrm{E}-05$ \\
\hline Phospholipid binding & down & $9.90 \mathrm{E}-05$ \\
\hline Cell cycle & up & 0.0001 \\
\hline Cytosol & down & 0.0001 \\
\hline Cytoskeletal protein binding & down & 0.0001 \\
\hline Response to endogenous stimulus & up & 0.0001 \\
\hline Gonad development & up & 0.0001 \\
\hline $\begin{array}{l}\text { Nucleobase, nucleoside, nucleotide and } \\
\text { nucleic acid transport }\end{array}$ & up & 0.0001 \\
\hline Nucleolus & up & 0.0001 \\
\hline Regulation of cytokine biosynthetic process & up & 0.0001 \\
\hline Rhythmic process & up & 0.0001 \\
\hline Reproductive structure development & up & 0.0002 \\
\hline Mitochondrion organization and biogenesis & up & 0.0002 \\
\hline Structural constituent of cytoskeleton & down & 0.0002 \\
\hline Sex differentiation & up & 0.0002 \\
\hline Transcription repressor activity & up & 0.0002 \\
\hline Peroxidase activity & down & 0.0002 \\
\hline $\begin{array}{l}\text { Oxidoreductase activity, acting on peroxide } \\
\text { as acceptor }\end{array}$ & down & 0.0002 \\
\hline
\end{tabular}

(Continued)
Table S2 (Continued)

A549 cells treated with $3 \mu$ M AZA (48 hours)

\begin{tabular}{lll}
\hline Biogroup name & Direction & $\boldsymbol{P}$ value \\
\hline Laminin-I complex & down & 0.0002 \\
Transcription cofactor activity & up & 0.0002 \\
Female sex differentiation & up & 0.0002 \\
Development of primary female sexual & up & 0.0002
\end{tabular}

characteristics

Oxidoreductase activity, acting on the $\mathrm{CH}-\mathrm{CH}$ down 0.0002

group of donors, NAD or NADP as acceptor

Nitrogen compound biosynthetic process

Cell structure disassembly during apoptosis

Amino acid transport

Acyl-CoA binding

Response to dsRNA

Neuron development

Integrator complex

Immune response

Protein dimerization activity

Laminin complex

Cofactor binding

Germ-line sex determination

Intramolecular oxidoreductase activity

DNA repair

Cell soma

Cellular morphogenesis during differentiation

RNA polymerase II transcription

factor activity

Regulation of epithelial cell proliferation

Regulation of biosynthetic process

UDP-glycosyltransferase activity

Pyridoxal phosphate binding

Lipid binding

Positive regulation of programmed cell death

Helicase activity

Cell redox homeostasis

Cell death

Death

Epithelial cell proliferation

Mesenchymal cell development

Ovulation

Positive regulation of locomotion

Positive regulation of cell motility

DNA catabolic process

Cell differentiation

Basal lamina

Insulin-like growth factor binding

up

0.0002

up $\quad 0.0003$

up $\quad 0.0003$

down $\quad 0.0003$

up $\quad 0.0003$

down $\quad 0.0003$

up $\quad 0.0003$

down $\quad 0.0003$

up $\quad 0.0004$

down $\quad 0.0004$

down $\quad 0.0004$

down $\quad 0.0004$

down $\quad 0.0004$

up $\quad 0.0004$

down $\quad 0.0004$

down $\quad 0.0004$

up $\quad 0.0005$

down $\quad 0.0005$

up $\quad 0.0005$

up $\quad 0.0005$

up $\quad 0.0005$

down $\quad 0.0005$

up $\quad 0.0005$

up $\quad 0.0006$

down $\quad 0.0006$

up $\quad 0.0006$

up $\quad 0.0006$

down $\quad 0.0006$

down $\quad 0.0006$

up $\quad 0.0006$

down $\quad 0.0006$

down $\quad 0.0006$

up $\quad 0.0006$

down $\quad 0.0006$

down $\quad 0.0007$

down $\quad 0.0007$

down $\quad 0.0007$

$\begin{array}{lll}\text { Sequestering of metal ion } & \text { down } & 0.0007 \\ \text { Neurotransmitter transport } & \text { up } & 0.0007\end{array}$

Neurotransmitter transport

Specific RNA polymerase II transcription up 0.0007

factor activity

Intramolecular oxidoreductase activity, down $\quad 0.0007$

transposing $\mathrm{C}=\mathrm{C}$ bonds

Cellular component disassembly up 0.0008

Heme binding down 0.0008

$\begin{array}{lll}\text { Tetrapyrrole binding down } & 0.0008\end{array}$

Presynaptic active zone up 0.0008

Amine transport up 0.0009

(Continued) 
Table S2 (Continued)

\begin{tabular}{lll}
\hline A549 cells treated with $3 \mu$ M AZA (48 hours) & \\
\hline Biogroup name & Direction & $\boldsymbol{P}$ value \\
\hline Sequestering of calcium ion & down & 0.0009 \\
Cell recognition & down & 0.0009 \\
Endoplasmic reticulum part & down & 0.0009 \\
Oxidoreductase activity, acting on the CH-OH & down & 0.00 I \\
group of donors, NAD or NADP as acceptor & & \\
Myosin binding & down & 0.00 I \\
Lyase activity & up & 0.00 I \\
Transferase activity, transferring & down & 0.001 \\
hexosyl groups & & \\
Neuron differentiation & down & 0.001 \\
\hline
\end{tabular}

Notes: Functional groupings of the modulated genes were determined using Gene Ontology classifications in NextBio. The top 200 biogroups most significantly regulated by AZA (at $3 \mu \mathrm{M}$ ) are shown.

Table S3 Top 196 biogroups modulated by decitabine (DAC) in A549 cells

\begin{tabular}{lll}
\hline A549 cells treated with 3 $\mu$ M DAC (48 hours) & \\
\hline Biogroup name & Direction & P value \\
\hline Mitosis & down & $2.00 \mathrm{E}-09$ \\
Cell cycle & down & $2.90 \mathrm{E}-09$ \\
Cell division & down & $5.70 \mathrm{E}-08$ \\
Transferase activity, transferring sulfur- & up & $5.80 \mathrm{E}-08$ \\
containing groups & & \\
Meiosis & down & I.50E-07 \\
Meiotic cell cycle & down & $1.70 \mathrm{E}-07$ \\
Response to DNA damage stimulus & down & $1.80 \mathrm{E}-07$ \\
Male gamete generation & up & $6.10 \mathrm{E}-07$ \\
Response to endogenous stimulus & down & $7.60 \mathrm{E}-07$ \\
Chromosome segregation & down & $2.10 \mathrm{E}-06$ \\
Aromatic compound metabolic process & up & $2.70 \mathrm{E}-06$ \\
Phenol metabolic process & up & $2.70 \mathrm{E}-06$ \\
Structural constituent of cytoskeleton & up & $5.10 \mathrm{E}-06$ \\
Sister chromatid cohesion & down & $5.90 \mathrm{E}-06$ \\
Cellular lipid catabolic process & up & $6.70 \mathrm{E}-06$ \\
DNA repair & down & $7.20 \mathrm{E}-06$ \\
Alkali metal ion binding & up & $9.00 \mathrm{E}-06$ \\
Regulation of neurotransmitter levels & up & I.IOE-05 \\
DNA damage response, signal transduction & down & I.30E-05 \\
Cofactor transporter activity & up & I.60E-05 \\
Sulfotransferase activity & up & $1.70 \mathrm{E}-05$ \\
Intermediate filament & up & $3.20 \mathrm{E}-05$ \\
Neurotransmitter:sodium symporter activity & up & $3.40 \mathrm{E}-05$ \\
Chromatin assembly & down & $3.90 \mathrm{E}-05$ \\
Neurotransmitter transporter activity & up & $4.60 \mathrm{E}-05$ \\
Cytokinesis & down & $5.10 \mathrm{E}-05$ \\
Chromosome & down & $5.30 \mathrm{E}-05$ \\
Mitotic spindle organization and biogenesis & down & $5.30 \mathrm{E}-05$ \\
Negative regulation of enzyme activity & up & $5.60 \mathrm{E}-05$ \\
Establishment of mitotic spindle localization & down & $6.50 \mathrm{E}-05$ \\
Establishment of spindle localization & down & $6.50 \mathrm{E}-05$ \\
Spindle localization & down & $6.50 \mathrm{E}-05$ \\
Retinol binding & up & $6.50 \mathrm{E}-05$ \\
Microtubule organizing center part & down & $7.60 \mathrm{E}-05$ \\
Mitotic sister chromatid segregation & down & $8.30 \mathrm{E}-05$ \\
\hline & up & $8.60 \mathrm{E}-05$ \\
\hline
\end{tabular}

(Continued)
Table S3 (Continued)

A549 cells treated with $3 \mu$ M DAC (48 hours)

\begin{tabular}{lll}
\hline Biogroup name & Direction & P value \\
\hline Sister chromatid segregation & down & $9.30 \mathrm{E}-05$ \\
Catabolic process & up & 0.0001 \\
Soluble fraction & up & 0.0001
\end{tabular}

Soluble fraction

Retinal binding

Positive regulation of programmed cell death

Steroid biosynthetic process

Response to stress

Gamma-tubulin complex

Mitotic chromosome condensation

Transporter activity

Phosphopyruvate hydratase complex

Amino acid derivative metabolic process

Vitamin binding

Lipid catabolic process

Nuclear chromosome

Retinoid binding

Isoprenoid binding

Homologous chromosome segregation

Meiotic chromosome segregation

Meiotic spindle organization and biogenesis

Cell differentiation

NADP binding

Steroid metabolic process

Lipid raft

Cohesin complex

Meiosis I

Sodium:potassium-exchanging ATPase complex

Negative regulation of cell proliferation

Actin binding

Nuclear matrix

Cytoskeletal protein binding

Protein kinase inhibitor activity

Cell proliferation

Cytoskeleton

Cytoskeleton organization and biogenesis

Fat cell differentiation

Hormone metabolic process

Positive regulation of progression through cell cycle

Kinase inhibitor activity

Oxidoreductase activity, acting on the $\mathrm{CH}-\mathrm{CH}$

group of donors, NAD or NADP as acceptor

Neurotransmitter transport

Membrane invagination

Endocytosis

Amide metabolic process

Spindle

Ion transport

Blastocyst growth

Interleukin binding

RNA export from nucleus

Tubulin binding

Epidermis development

Neurotransmitter metabolic process

Translation activator activity

Spindle pole

Synaptic transmission

Intracellular cyclic nucleotide activated cation

channel complex $\begin{array}{ll}\text { up } & 0.0001 \\ \text { up } & 0.0001\end{array}$

up $\quad 0.0001$

up $\quad 0.0002$

down $\quad 0.0002$

down $\quad 0.0002$

down $\quad 0.0002$

up $\quad 0.0002$

up $\quad 0.0003$

up $\quad 0.0003$

up $\quad 0.0003$

down $\quad 0.0003$

up $\quad 0.0003$

down $\quad 0.0003$

down $\quad 0.0003$

down $\quad 0.0003$

up $\quad 0.0003$

down $\quad 0.0004$

up $\quad 0.0004$

up $\quad 0.0004$

down $\quad 0.0004$

down $\quad 0.0004$

up $\quad 0.0004$

up $\quad 0.0004$

down $\quad 0.0005$

down $\quad 0.0005$

up $\quad 0.0005$

up $\quad 0.0006$

down $\quad 0.0006$

down $\quad 0.0006$

down $\quad 0.0006$

up $\quad 0.0006$

down $\quad 0.0006$

up $\quad 0.0006$

down $\quad 0.0007$

up $\quad 0.0007$

down $\quad 0.0008$

down $\quad 0.0008$

up $\quad 0.0008$

up $\quad 0.0009$

down $\quad 0.0009$

down $\quad 0.0009$

down $\quad 0.0009$

up $\quad 0.0009$

up $\quad 0.0011$

up $\quad 0.0011$

down 0.0011

up $\quad 0.0012$

up $\quad 0.0012$ up $\quad 0.0002$

up $\quad 0.0003$

down $\quad 0.0005$

down $\quad 0.0008$

down $\quad 0.0009$ 
Table S3 (Continued)

\begin{tabular}{|c|c|c|}
\hline \multicolumn{3}{|c|}{ A549 cells treated with $3 \mu$ M DAC (48 hours) } \\
\hline Biogroup name & Direction & $P$ value \\
\hline Biogenic amine metabolic process & up & 0.0012 \\
\hline Cell fate determination & up & 0.0013 \\
\hline $\begin{array}{l}\text { Oxidoreductase activity, acting on iron-sulfur } \\
\text { proteins as donors }\end{array}$ & up & 0.0013 \\
\hline lon channel activity & up & 0.0013 \\
\hline Lipoprotein binding & down & 0.0014 \\
\hline Positive regulation of neurogenesis & down & 0.0014 \\
\hline Cytosol & up & 0.0018 \\
\hline Microtubule organizing center & down & 0.002 \\
\hline Microtubule & down & 0.002 \\
\hline Glutathione peroxidase activity & up & 0.0021 \\
\hline Odontogenesis & down & 0.0022 \\
\hline Passive transmembrane transporter activity & up & 0.0022 \\
\hline Transmission of nerve impulse & up & 0.0023 \\
\hline Oxidoreductase activity, acting on the $\mathrm{CH}-\mathrm{NH}$ & down & 0.0024 \\
\hline \multicolumn{3}{|l|}{ group of donors, NAD or NADP as acceptor } \\
\hline Dynein binding & down & 0.0024 \\
\hline Humoral immune response & down & 0.0024 \\
\hline Ectoderm development & up & 0.0025 \\
\hline Arginine metabolic process & up & 0.0025 \\
\hline Myosin binding & down & 0.0025 \\
\hline Lipid biosynthetic process & up & 0.0026 \\
\hline Muscle contraction & up & 0.0027 \\
\hline Mitochondrion organization and biogenesis & up & 0.0027 \\
\hline Fat-soluble vitamin metabolic process & up & 0.0028 \\
\hline Female gamete generation & down & 0.0028 \\
\hline Urea cycle intermediate metabolic process & up & 0.0029 \\
\hline Inclusion body & down & 0.0029 \\
\hline Folic acid transporter activity & down & 0.0029 \\
\hline Protein heterodimerization activity & down & 0.003 \\
\hline Angiogenesis & up & 0.003 \\
\hline Replication fork & down & 0.0031 \\
\hline Nucleoside metabolic process & down & 0.0031 \\
\hline Regulation of axonogenesis & down & 0.0032 \\
\hline Anatomical structure formation & up & 0.0033 \\
\hline Protein kinase regulator activity & up & 0.0034 \\
\hline Lipid metabolic process & up & 0.0037 \\
\hline Glycoprotein binding & up & 0.0037 \\
\hline Pyridoxal phosphate binding & up & 0.0037 \\
\hline Blood vessel morphogenesis & up & 0.004 \\
\hline Carbohydrate metabolic process & up & 0.0041 \\
\hline Tissue regeneration & up & 0.0041 \\
\hline Regeneration & up & 0.0041 \\
\hline Germ cell development & up & 0.0042 \\
\hline Growth factor binding & down & 0.0042 \\
\hline Peptide transporter activity & up & 0.0043 \\
\hline Nitrogen compound biosynthetic process & up & 0.0044 \\
\hline Cytokine binding & down & 0.0044 \\
\hline Nitric oxide metabolic process & up & 0.0047 \\
\hline Nitric oxide biosynthetic process & up & 0.0047 \\
\hline Centrosome & down & 0.0047 \\
\hline Embryonic morphogenesis & down & 0.0048 \\
\hline Regulation of neurogenesis & down & 0.0048 \\
\hline Oxidoreductase activity, acting on the & up & 0.0048 \\
\hline \multicolumn{3}{|l|}{ aldehyde or oxo group of donors } \\
\hline Cytokinesis during cell cycle & down & 0.0049 \\
\hline Cell-cell signaling & up & 0.005 \\
\hline Calmodulin binding & up & 0.005 \\
\hline
\end{tabular}

(Continued)
Table S3 (Continued)

A549 cells treated with $3 \mu$ M DAC (48 hours)

\begin{tabular}{lll}
\hline Biogroup name & Direction & $\boldsymbol{P}$ value \\
\hline Structure-specific DNA binding & down & $0.005 \mathrm{I}$ \\
Oxidoreductase activity, acting on the & down & $0.005 \mathrm{I}$ \\
$\mathrm{CH}-\mathrm{CH}$ group of donors & & \\
Peroxidase activity & up & $0.005 \mathrm{I}$
\end{tabular}

Oxidoreductase activity, acting on peroxide up 0.005 I

as acceptor

Microfibril

Protein-DNA complex assembly

Vasculature development

Excretion

mRNA transport

Identical protein binding

Vitamin transporter activity

Response to organic cyclic substance

Response to alkaloid

Kinase regulator activity

Chromatin

Electron carrier activity

Vitamin biosynthetic process

RNA transport

Nucleic acid transport

Establishment of RNA localization

Protein domain specific binding

Homophilic cell adhesion

RNA localization

Hormone biosynthetic process

Protein dimerization activity

RNA binding

Blastocyst development

Cyclin binding

Nucleobase, nucleoside, nucleotide and

nucleic acid transport

Cartilage development

up $\quad 0.0052$

down $\quad 0.0052$

up $\quad 0.0054$

up $\quad 0.0055$

down $\quad 0.0056$

up $\quad 0.0056$

down $\quad 0.0057$

up $\quad 0.0059$

up $\quad 0.0059$

up $\quad 0.006$

down $\quad 0.006$

up $\quad 0.0061$

down $\quad 0.0062$

down $\quad 0.0067$

down $\quad 0.0067$

down $\quad 0.0067$

up $\quad 0.0068$

down $\quad 0.0068$

down $\quad 0.0069$

up $\quad 0.007$

down $\quad 0.007$

down $\quad 0.0073$

down $\quad 0.0074$

up $\quad 0.0075$

down $\quad 0.0077$

$\begin{array}{ll}\text { down } & 0.0077\end{array}$

Folic acid binding down 0.0079

Positive regulation of developmental process down 0.008 I

$\begin{array}{lll}\text { Chordate embryonic development down } & 0.0082\end{array}$

NAD binding

Cofactor binding

Vesicle docking during exocytosis

Developmental maturation

Hydrolase activity, acting on carbon-nitrogen

(but not peptide) bonds, in cyclic amidines

Lysosome

Embryonic digit morphogenesis

DNA helicase activity

Axon guidance

Membrane docking

Vesicle docking

Voltage-gated sodium channel complex

mRNA binding

Establishment of organelle localization

Vitamin metabolic process

Oxidoreductase activity, acting on paired

$\begin{array}{ll}\text { down } & 0.0082 \\ \text { up } & 0.0082\end{array}$

up $\quad 0.0082$

up $\quad 0.0084$

up $\quad 0.0085$

up $\quad 0.0086$

donors, with incorporation or reduction of

up $\quad 0.0086$

down $\quad 0.0086$

down $\quad 0.0089$

down $\quad 0.0091$

up $\quad 0.0093$

up $\quad 0.0093$

down $\quad 0.0093$

up $\quad 0.0094$

down $\quad 0.0096$

up $\quad 0.0096$

down $\quad 0.0099$ molecular oxygen

Notes: Functional groupings of the modulated genes were determined using Gene Ontology classifications in NextBio. The top 196 biogroups most significantly regulated by DAC (at $3 \mu \mathrm{M})$ are shown. 
Table S4 Top 200 biogroups modulated by azacitidine (AZA) in HI 299 cells

\begin{tabular}{|c|c|c|}
\hline \multicolumn{3}{|c|}{ HI 299 cells treated with $3 \mu \mathrm{M}$ AZA (48 hours) } \\
\hline Biogroup name & Direction & $P$ value \\
\hline Transcription & up & $1.90 \mathrm{E}-25$ \\
\hline Cell cycle & down & $7.60 \mathrm{E}-25$ \\
\hline Mitosis & down & $8.00 \mathrm{E}-24$ \\
\hline Cell division & down & $1.00 \mathrm{E}-22$ \\
\hline Cytoskeleton & down & $5.60 \mathrm{E}-14$ \\
\hline Microtubule & down & I.30E-13 \\
\hline Spindle & down & I.80E-13 \\
\hline Mitochondrion & down & $1.80 \mathrm{E}-12$ \\
\hline Sterol metabolic process & down & I.40E-I I \\
\hline Chromosome & down & I.20E-10 \\
\hline Alcohol metabolic process & down & $2.20 \mathrm{E}-10$ \\
\hline Ligase activity & up & $2.40 \mathrm{E}-10$ \\
\hline Lipid biosynthetic process & down & $2.70 \mathrm{E}-10$ \\
\hline Steroid biosynthetic process & down & $3.00 \mathrm{E}-10$ \\
\hline Mitotic sister chromatid segregation & down & $1.90 \mathrm{E}-09$ \\
\hline Steroid metabolic process & down & $2.50 \mathrm{E}-09$ \\
\hline Sister chromatid segregation & down & $2.90 \mathrm{E}-09$ \\
\hline Endoplasmic reticulum & down & $3.60 \mathrm{E}-09$ \\
\hline Envelope & down & $4.70 \mathrm{E}-09$ \\
\hline Lipid metabolic process & down & $2.60 \mathrm{E}-08$ \\
\hline Response to nutrient & down & $7.00 \mathrm{E}-08$ \\
\hline Collagen binding & down & I.60E-07 \\
\hline Centrosome & down & I.70E-07 \\
\hline Wound healing & down & I.90E-07 \\
\hline Response to nutrient levels & down & 2.00E-07 \\
\hline Intramolecular oxidoreductase activity & down & $2.50 \mathrm{E}-07$ \\
\hline Response to extracellular stimulus & down & $2.70 \mathrm{E}-07$ \\
\hline Mitochondrial membrane & down & $2.80 \mathrm{E}-07$ \\
\hline Microtubule organizing center & down & $2.80 \mathrm{E}-07$ \\
\hline Acid-amino acid ligase activity & up & 3. $10 \mathrm{E}-07$ \\
\hline Cell proliferation & down & $3.60 \mathrm{E}-07$ \\
\hline Blood coagulation & down & $3.70 \mathrm{E}-07$ \\
\hline Establishment of chromosome localization & down & $4.40 \mathrm{E}-07$ \\
\hline Coagulation & down & $4.90 \mathrm{E}-07$ \\
\hline Chromosome segregation & down & $5.00 \mathrm{E}-07$ \\
\hline Nitrogen compound catabolic process & down & 5.20E-07 \\
\hline Kinase binding & up & 5.30E-07 \\
\hline Beta-catenin binding & down & $5.50 \mathrm{E}-07$ \\
\hline Nucleoplasm & up & 6. $10 \mathrm{E}-07$ \\
\hline Enzyme inhibitor activity & down & $8.80 \mathrm{E}-07$ \\
\hline Alcohol catabolic process & down & $9.80 \mathrm{E}-07$ \\
\hline Hemostasis & down & I.IOE-06 \\
\hline Transcription cofactor activity & up & I.I0E-06 \\
\hline Transcription repressor activity & up & I.20E-06 \\
\hline Midbody & down & I.30E-06 \\
\hline Ligase activity, forming carbon-nitrogen bonds & up & I.70E-06 \\
\hline Establishment of organelle localization & down & $2.00 \mathrm{E}-06$ \\
\hline Germ-line sex determination & down & 2.00E-06 \\
\hline Oligosaccharyl transferase complex & down & 2. $10 \mathrm{E}-06$ \\
\hline Response to external stimulus & down & $2.20 \mathrm{E}-06$ \\
\hline $\begin{array}{l}\text { Oxidoreductase activity, acting on the } \mathrm{CH}-\mathrm{NH} \\
\text { group of donors, NAD or NADP as acceptor }\end{array}$ & down & $2.20 \mathrm{E}-06$ \\
\hline Amine catabolic process & down & $2.20 \mathrm{E}-06$ \\
\hline Cytoskeleton organization and biogenesis & down & $2.20 \mathrm{E}-06$ \\
\hline Cofactor binding & down & $2.30 \mathrm{E}-06$ \\
\hline
\end{tabular}

Table S4 (Continued)

HI 299 cells treated with $3 \mu$ M AZA (48 hours)

\begin{tabular}{lll}
\hline Biogroup name & Direction & P value \\
\hline Coenzyme binding & down & $2.70 \mathrm{E}-06$ \\
Transcription corepressor activity & up & $3.00 \mathrm{E}-06$ \\
Cell differentiation & up & $3.20 \mathrm{E}-06$ \\
mRNA binding & down & $3.30 \mathrm{E}-06$ \\
Meiotic chromosome segregation & down & $3.60 \mathrm{E}-06$ \\
Homologous chromosome segregation & down & $3.60 \mathrm{E}-06$ \\
Nuclear envelope-endoplasmic reticulum & down & $3.90 \mathrm{E}-06$ \\
network & & \\
Oxidor & &
\end{tabular}

Oxidoreductase activity, acting on the $\mathrm{CH}-\mathrm{CH}$ down $5.00 \mathrm{E}-06$ group of donors, NAD or NADP as acceptor

Intramolecular oxidoreductase activity,

down $\quad 5.30 \mathrm{E}-06$

transposing $\mathrm{C}=\mathrm{C}$ bonds

Mitotic chromosome condensation down 5.50E-06

Endoplasmic reticulum part down 5.50E-06

Transcription factor binding up $5.60 \mathrm{E}-06$

Organic acid transport up $5.70 \mathrm{E}-06$

Carboxylic acid transport up $\quad 5.70 \mathrm{E}-06$

Acyl-CoA binding down 5.70E-06

DNA-directed RNA polymerase II, up $5.80 \mathrm{E}-06$

holoenzyme

Interphase of mitotic cell cycle down 6.00E-06

Primary sex determination down 6.00E-06

Cell-matrix adhesion down 6.20E-06

Hormone activity down 6.30E-06

Organic acid transmembrane transporter up $6.30 \mathrm{E}-06$

activity

Mitochondrial inner membrane down 7.30E-06

Cell-substrate adhesion down 7.60E-06

Transcription activator activity up 7.70E-06

Mitotic spindle organization and biogenesis down $7.90 \mathrm{E}-06$

Lyase activity down 8.10E-06

Sterol transport down 8.70E-06

Arginine metabolic process down 8.70E-06

Chromatin assembly down I.00E-05

Nitrogen compound biosynthetic process down I.IOE-05

RNA polymerase II transcription factor up I.I0E-05

activity

Transaminase activity

I.20E-05

Meiotic spindle organization and biogenesis down I.30E-05

Organelle localization down I.40E-05

Isomerase activity down $1.40 \mathrm{E}-05$

Interphase down $1.40 \mathrm{E}-05$

Urea cycle intermediate metabolic process down I.50E-05

$\begin{array}{lll}\text { Fatty acid biosynthetic process down I.70E-05 } & \end{array}$

Receptor binding down $1.70 \mathrm{E}-05$

$\begin{array}{ll}\text { Regulation of body fluids down } \quad 1.80 \mathrm{E}-05 & \end{array}$

Condensin complex down I.80E-05

$\begin{array}{lll}\text { Regulation of coagulation down } & \text { I.90E-05 }\end{array}$

Nuclear envelope down 2.20E-05

Caveola down 2.30E-05

Organic acid biosynthetic process down $2.30 \mathrm{E}-05$

Meiotic cell cycle down 2.30E-05

Amino acid transport up $2.50 \mathrm{E}-05$

NADP binding down 2.80E-05

Protein dimerization activity up $2.90 \mathrm{E}-05$

\begin{tabular}{lll} 
Spindle pole down & $3.40 \mathrm{E}-05$ \\
\hline
\end{tabular}

(Continued) 
Table S4 (Continued)

\section{HI 299 cells treated with $3 \mu$ M AZA (48 hours)}

Biogroup name

Transferase activity, transferring nitrogenous groups

Nucleoside metabolic process

Structural constituent of cytoskeleton

Carbohydrate catabolic process

Endoplasmic reticulum membrane

Nucleosome

Nucleotide catabolic process

Cellular chemical homeostasis

Cellular ion homeostasis

Cytokinesis

Muscle cell differentiation

Myeloid cell differentiation

Catabolic process

Oxygen and reactive oxygen species

metabolic process

Chromatin

Epidermis development

Oxidoreductase activity, acting on the

$\mathrm{CH}-\mathrm{NH}$ group of donors

SNARE complex

Ligase activity, forming carbon-oxygen bonds

Ligase activity, forming aminoacyl-tRNA and

related compounds

Soluble fraction

Endopeptidase inhibitor activity

Protease inhibitor activity

Small protein conjugating enzyme activity

AP-type membrane coat adaptor complex

Cell-cell signaling

Amine transport

Response to DNA damage stimulus

Male sex determination

Cell-cell adhesion

Protein heterodimerization activity

Enzyme binding

Oxidoreductase activity, acting on paired

donors, with incorporation or reduction

of molecular oxygen

Ectoderm development

Positive regulation of progression through

cell cycle

One-carbon compound metabolic process

Heterogeneous nuclear ribonucleoprotein

complex

Response to stress

Response to endogenous stimulus

Cell death

Death

Meiosis

Dioxygenase activity

Oxidoreductase activity, acting on single

donors with incorporation of molecular

oxygen, incorporation of two atoms of oxygen

Isoprenoid biosynthetic process

$\begin{array}{ll}\text { Direction } & \boldsymbol{P} \text { value } \\ \text { up } & 3.50 \mathrm{E}-05 \\ \text { up } & 3.60 \mathrm{E}-05\end{array}$

down 3.80E-05

down 3.90E-05

down 4.IOE-05

down 4.30E-05

down 4.40E-05

down 4.60E-05

down 4.70E-05

down 4.70E-05

down 4.90E-05

up $\quad 5.00 \mathrm{E}-05$

up $\quad 5.20 \mathrm{E}-05$

down 5.20E-05

down $\quad 5.20 \mathrm{E}-05$

down $\quad 5.30 \mathrm{E}-05$

down 5.40E-05

down $\quad 5.60 \mathrm{E}-05$

up

up

up

up

down

down

up

down

down

up

up

down

down

down

up

down

5.60E-05

5.70E-05

5.70E-05

5.80E-05

$5.90 \mathrm{E}-05$

$5.90 \mathrm{E}-05$

$6.00 \mathrm{E}-05$

$6.40 \mathrm{E}-05$

6.70E-05

6.80E-05

$7.20 \mathrm{E}-05$

7.20E-05

8.00E-05

$8.00 \mathrm{E}-05$

$8.40 \mathrm{E}-05$

9. $10 \mathrm{E}-05$

down

down

9.40E-05

0.0001

down $\quad 0.0001$

down $\quad 0.0001$

down $\quad 0.0001$

up $\quad 0.0001$

up $\quad 0.0001$

up $\quad 0.0001$

down $\quad 0.0001$

up $\quad 0.000$ I

up $\quad 0.000$ I

down

0.0001

Continued
Table S4 (Continued)

HI 299 cells treated with $3 \mu$ M AZA (48 hours)

\begin{tabular}{lll}
\hline Biogroup name & Direction & $\boldsymbol{P}$ value \\
\hline Carbon-carbon lyase activity & down & $0.000 \mathrm{I}$ \\
Lipid digestion & down & $0.000 \mathrm{I}$ \\
Nitric oxide metabolic process & down & $0.000 \mathrm{I}$ \\
Nitric oxide biosynthetic process & down & $0.000 \mathrm{I}$ \\
Cellular homeostasis & down & $0.000 \mathrm{I}$ \\
Positive regulation of locomotion & down & $0.000 \mathrm{I}$ \\
Positive regulation of cell motility & down & $0.000 \mathrm{I}$ \\
Sulfur compound biosynthetic process & up & $0.000 \mathrm{I}$ \\
Proton-transporting ATP synthase complex, & down & 0.0001 \\
catalytic core F(I) & & \\
Mitochondrial proton-transporting ATP & down & 0.0002
\end{tabular}

synthase complex

Muscle development

Integrator complex

Caspase inhibitor activity

Fatty acid binding

Isoprenoid metabolic process

Blood vessel morphogenesis

Vasculogenesis

Kinetochore

Low-density lipoprotein binding

Cell structure disassembly during

apoptosis

Endoplasmic reticulum lumen

Negative regulation of multicellular

down

0.0002

organismal process

Intestinal absorption

Organelle outer membrane

Proton-transporting two-sector ATPase

complex, catalytic domain

Regulation of transforming growth factor

beta receptor signaling pathway

Clathrin adaptor complex

Fatty acid metabolic process

Replication fork

Lipoprotein binding

Insemination

Behavior

Leukocyte differentiation

Single-stranded RNA binding

up

up

0.0002

up $\quad 0.0002$

down $\quad 0.0002$

down $\quad 0.0002$

down $\quad 0.0002$

up $\quad 0.0002$

up $\quad 0.0002$

down $\quad 0.0002$

down $\quad 0.0002$

up $\quad 0.0002$

down $\quad 0.0002$

down $\quad 0.0002$

down $\quad 0.0002$

down $\quad 0.0002$

down $\quad 0.0002$

down $\quad 0.0002$

down $\quad 0.0002$

down $\quad 0.0003$

down $\quad 0.0003$

down $\quad 0.0003$

up $\quad 0.0003$

down $\quad 0.0003$

up $\quad 0.0003$

down $\quad 0.0003$

up $\quad 0.0003$

up $\quad 0.0003$

Oxidoreductase activity, acting on single

donors with incorporation of

molecular oxygen

Hemopoiesis

Outer kinetochore of condensed

up

0.0003

chromosome

Response to virus

Vasculature development

DNA-directed RNA polymerase complex

Perinuclear region of cytoplasm

Sterol binding

Generation of precursor metabolites and

energy

Copulation

down

0.0003

Spindle localization

down

0.0004

0.0004

(Continued) 
Table S4 (Continued)

\begin{tabular}{lll}
\hline HI299 cells treated with $3 \mu$ M AZA (48 hours) & \\
\hline Biogroup name & Direction & P value \\
\hline Establishment of mitotic spindle localization & down & 0.0004 \\
Establishment of spindle localization & down & 0.0004 \\
Neural crest cell development & down & 0.0004 \\
GTPase inhibitor activity & down & 0.0004 \\
\hline
\end{tabular}

Notes: Functional groupings of the modulated genes were determined using Gene Ontology classifications in NextBio. The top 200 biogroups most significantly regulated by AZA (at $3 \mu \mathrm{M}$ ) are shown.

Table S5 Top 200 biogroups modulated by decitabine (DAC) in $\mathrm{HI} 299$ cells

\begin{tabular}{|c|c|c|}
\hline \multicolumn{3}{|c|}{ HI 299 cells treated with $3 \mu$ MAC (48 hours) } \\
\hline Biogroup name & Direction & $P$ value \\
\hline Cofactor binding & down & $4.70 \mathrm{E}-12$ \\
\hline Lipid metabolic process & down & 5. $10 \mathrm{E}-12$ \\
\hline Cell differentiation & up & $2.50 \mathrm{E}-08$ \\
\hline Coenzyme binding & down & $3.70 \mathrm{E}-08$ \\
\hline Transcription & up & I.00E-07 \\
\hline Inner ear development & up & 2.20E-07 \\
\hline Cell fate determination & up & $2.50 \mathrm{E}-07$ \\
\hline Fatty acid metabolic process & down & $2.90 \mathrm{E}-07$ \\
\hline Collagen binding & up & 4.90E-07 \\
\hline $\begin{array}{l}\text { Oxidoreductase activity, acting on the } \mathrm{CH}-\mathrm{OH} \\
\text { group of donors, NAD or NADP as acceptor }\end{array}$ & down & I.20E-06 \\
\hline Enzyme inhibitor activity & up & I.30E-06 \\
\hline Nucleosome & up & I.30E-06 \\
\hline Aldehyde metabolic process & down & I.40E-06 \\
\hline Sensory organ development & up & $2.30 \mathrm{E}-06$ \\
\hline $\begin{array}{l}\text { Oxidoreductase activity, acting on } \mathrm{CH}-\mathrm{OH} \\
\text { group of donors }\end{array}$ & down & $2.50 \mathrm{E}-06$ \\
\hline Response to external stimulus & up & $2.80 \mathrm{E}-06$ \\
\hline Hormone biosynthetic process & up & $3.00 \mathrm{E}-06$ \\
\hline CoA-ligase activity & down & 4.00E-06 \\
\hline Insulin-like growth factor binding & up & $4.20 \mathrm{E}-06$ \\
\hline Response to stress & up & 4.40E-06 \\
\hline Mitochondrion & down & $5.20 \mathrm{E}-06$ \\
\hline Acid-thiol ligase activity & down & $6.30 \mathrm{E}-06$ \\
\hline Proteinaceous extracellular matrix & up & 7.40E-06 \\
\hline Transcription repressor activity & up & 7.90E-06 \\
\hline Extracellular matrix & up & 8.60E-06 \\
\hline Muscle cell differentiation & up & $9.40 \mathrm{E}-06$ \\
\hline Response to wounding & up & $9.50 \mathrm{E}-06$ \\
\hline Alcohol metabolic process & down & $9.90 \mathrm{E}-06$ \\
\hline Enzyme regulator activity & up & $9.90 \mathrm{E}-06$ \\
\hline Neurotransmitter metabolic process & up & I.00E-05 \\
\hline Muscle fiber development & up & I.IOE-05 \\
\hline Skeletal muscle fiber development & up & I.I0E-05 \\
\hline Peroxisome & down & I. I0E-05 \\
\hline Microbody & down & I.I0E-05 \\
\hline Ligase activity, forming carbon-sulfur bonds & down & I.40E-05 \\
\hline Regulation of epidermis development & up & 2.00E-05 \\
\hline Cell fate commitment & up & 2.20E-05 \\
\hline Hormone metabolic process & up & 2.20E-05 \\
\hline Sterol metabolic process & down & 2.30E-05 \\
\hline Inflammatory response & up & $2.30 \mathrm{E}-05$ \\
\hline
\end{tabular}

(Continued)
Table S5 (Continued)

HI 299 cells treated with $3 \mu$ M DAC (48 hours)

\begin{tabular}{lll}
\hline Biogroup name & Direction & $\boldsymbol{P}$ value \\
\hline $\begin{array}{l}\text { Oxidoreductase activity, acting on the } \mathrm{CH}-\mathrm{CH} \\
\text { group of donors, NAD or NADP as acceptor }\end{array}$ & down & $2.60 \mathrm{E}-05$ \\
\end{tabular}

Death

Cell death

Steroid metabolic process

Lipid biosynthetic process

Lyase activity

Glycosaminoglycan binding

Polysaccharide binding

Pyridoxal phosphate binding

Muscle development

Nitrogen compound biosynthetic process

Protease inhibitor activity

Endopeptidase inhibitor activity

Phosphatase activator activity

Phenol metabolic process

Epidermis development

Regulation of neurotransmitter levels

Pattern binding

Cofactor catabolic process

Positive regulation of developmental process

Vitamin binding

Oxidoreductase activity, acting on the

up

3.20E-05

$\mathrm{CH}-\mathrm{CH}$ group of donors

Amino acid derivative metabolic process

Chromatin assembly

Protein-DNA complex assembly

Amino acid derivative biosynthetic process

Positive regulation of cell differentiation

Acute inflammatory response

Dopamine metabolic process

Growth factor binding

Endothelial cell development

Transcription corepressor activity

Keratinocyte differentiation

Ectoderm development

Cellular respiration

RNA polymerase II transcription elongation

up 3.20E-05

down 3.50E-05

down 3.80E-05

down 4.10E-05

up 4.50E-05

up $\quad 5.30 \mathrm{E}-05$

down 5.50E-05

up 6.70E-05

down 6.90E-05

up 7.60E-05

up 7.60E-05

up $\quad 8.00 \mathrm{E}-05$

up $8.40 \mathrm{E}-05$

up $8.50 \mathrm{E}-05$

up $9.20 \mathrm{E}-05$

up $\quad 9.60 \mathrm{E}-05$

down 9.80E-05

up I.00E-04

down $\quad 0.0001$

down $\quad 0.0001$

factor activity

Angiogenesis

Calcium-dependent phospholipid binding

Suckling behavior

Oxidoreductase activity, acting on the

aldehyde or oxo group of donors, NAD

or NADP as acceptor

Germ-line sex determination down 0.0003

RNA polymerase II transcription factor activity up 0.0003

Protein kinase inhibitor activity up 0.0004

Translation activator activity up $\quad 0.0004$

Regulation of Notch signaling pathway up 0.0004

$\begin{array}{lll}\text { Fatty acid biosynthetic process down } & 0.0004\end{array}$

Kinase inhibitor activity up 0.0004

Regulation of cell differentiation up $\quad 0.0004$

ER-Golgi intermediate compartment up 0.0005

UDP-glycosyltransferase activity down $\quad 0.0005$

Cell maturation $\quad$ up $\quad 0.0005$

(Continued) 
Table S5 (Continued)

HI299 cells treated with $3 \mu$ M DAC (48 hour
Biogroup name
Cell surface
Inner ear receptor cell fate commitment
Organic acid biosynthetic process
Negative regulation of signal transduction
Hydro-Lyase activity
Epidermal cell differentiation
Inner ear morphogenesis
Regulation of cell growth
Response to bacterium
Blood vessel morphogenesis
Carbohydrate metabolic process
Lipoprotein binding
Multicellular organismal movement
Aromatic compound metabolic process
Amine biosynthetic process
tRNA binding
Cell migration
Transcription elongation factor complex
Glutathione peroxidase activity
Oxidoreductase activity, acting on the CH-NH
group of donors, NAD or NADP as acceptor
Primary sex determination
Negative regulation of cell differentiation
Defense response to bacterium
Nuclear envelope
Ear morphogenesis
Ligase activity, forming carbon-oxygen bonds
Ligase activity, forming aminoacyl-tRNA and
related compounds
Generation of precursor metabolites and
energy
Developmental maturation
Pers

Peripheral nervous system development

Extracellular matrix structural constituent

Oxidoreductase activity, acting on the

aldehyde or oxo group of donors

Biogenic amine metabolic process

Epidermis morphogenesis

Endothelial cell differentiation

Endoplasmic reticulum

Carbon-oxygen lyase activity

Germ cell development

Cell proliferation

Peroxidase activity

Oxidoreductase activity, acting on peroxide

as acceptor

Specific RNA polymerase II transcription

factor activity

Positive regulation of programmed cell death

Response to nutrient levels

Myeloid cell differentiation

Lung development

Oxidoreductase activity, acting on paired

donors, with incorporation or reduction

of molecular oxygen

Vasculature development

up $\quad 0.0017$

down $\quad 0.0005$

0.0005

down $\quad 0.0005$

up $\quad 0.0006$

down $\quad 0.0006$

up $\quad 0.0007$

up $\quad 0.0007$

up $\quad 0.0007$

up $\quad 0.0007$

up $\quad 0.0007$

down $\quad 0.0007$

down $\quad 0.0007$

down $\quad 0.0008$

up $\quad 0.0008$

down $\quad 0.0008$

down $\quad 0.0008$

up $\quad 0.0008$

up $\quad 0.0009$

up $\quad 0.0009$

down $\quad 0.0009$

down $\quad 0.0009$

up $\quad 0.001$

up $\quad 0.001$

down $\quad 0.001$

up $\quad 0.0011$

down $\quad 0.0011$

down 0.0011

down $\quad 0.0011$

up $\quad 0.0011$

down $\quad 0.0011$

up $\quad 0.0012$

down $\quad 0.0012$

up $\quad 0.0012$

down $\quad 0.0013$

down $\quad 0.0013$

down $\quad 0.0013$

down $\quad 0.0015$

up $\quad 0.0015$

up $\quad 0.0015$

up $\quad 0.0015$

up $\quad 0.0016$

down $\quad 0.0016$

up $\quad 0.0016$

up $\quad 0.0017$

down $\quad 0.0017$
Table S5 (Continued)

HI299 cells treated with $3 \mu$ M DAC (48 hours)

\begin{tabular}{ll} 
Direction & $\boldsymbol{P}$ value \\
\hline down & 0.0005
\end{tabular}

up $\quad 0.0013$

up $\quad 0.0014$

(Continued)

\begin{tabular}{lll}
\hline Biogroup name & Direction & $\boldsymbol{P}$ value \\
\hline Respiratory tube development & up & 0.0018 \\
Oxidoreductase activity, acting on single & down & 0.0018
\end{tabular}

xidoreductase activity, acting on single

ors with incorporation of molecula

oxygen, incorporation of two atoms of oxygen

Dioxygenase activity

Negative regulation of enzyme activity

Odontogenesis

Positive regulation of locomotion

Positive regulation of cell motility

Cell cycle

Anatomical structure formation

Cell growth

Regulation of cell size

NAD binding

Steroid biosynthetic process

Response to extracellular stimulus

Endocytosis

Membrane invagination

Oxidoreductase activity, acting on single

down $\quad 0.0018$

up $\quad 0.0019$

up $\quad 0.0019$

down $\quad 0.0019$

down $\quad 0.0019$

up $\quad 0.0019$

up $\quad 0.002$

up $\quad 0.0021$

up $\quad 0.0021$

down $\quad 0.0021$

down $\quad 0.0022$

down $\quad 0.0022$

down $\quad 0.0023$

down $\quad 0.0023$

down $\quad 0.0025$

donors with incorporation of molecular oxygen

Musculoskeletal movement

down $\quad 0.0025$

Brain development

Immune system development

Negative regulation of cell growth

Negative regulation of cell size

Envelope

Negative regulation of developmental process

Chromatin

mRNA binding

Antioxidant activity

Selenium binding

Receptor signaling protein serine/threonine

kinase activity

Outer membrane-bounded periplasmic space

Cell envelope

Axon

Transferase activity, transferring hexosyl groups

Energy derivation by oxidation of organic

compounds

Response to reactive oxygen species

Meiosis

Meiotic cell cycle

Enzyme activator activity

Hemopoiesis

Positive regulation of biosynthetic process

Regulation of transforming growth factor

up $\quad 0.0026$

up $\quad 0.0027$

down $\quad 0.0028$

down $\quad 0.0028$

down $\quad 0.0029$

up $\quad 0.0029$

up $\quad 0.003$

up $\quad 0.0032$

up $\quad 0.0033$

up $\quad 0.0035$

down $\quad 0.0036$

down $\quad 0.0036$

down $\quad 0.0036$

up $\quad 0.0036$

down $\quad 0.0038$

down $\quad 0.0038$

beta receptor signaling pathway

FAD binding

Negative regulation of growth

Defense response to Gram-positive bacterium

Sensory perception of light stimulus

Catabolic process

Hemopoietic or lymphoid organ development

Positive regulation of protein metabolic process

Intermediate filament

$\begin{array}{ll}\text { up } & 0.0038 \\ \text { up } & 0.0038\end{array}$

up $\quad 0.0038$

up $\quad 0.0039$

up $\quad 0.0043$

up $\quad 0.0043$

down $\quad 0.0043$

Ras GTPase activator activity

down $\quad 0.0044$

down $\quad 0.0045$

up $\quad 0.0048$

down $\quad 0.0048$

down $\quad 0.0049$

up $\quad 0.005$

up $\quad 0.0051$

up $\quad 0.005$ I

down $\quad 0.0052$

(Continued) 
Table S5 (Continued)

\begin{tabular}{lll}
\hline HI 299 cells treated with $3 \mu$ M DAC (48 hours) & \\
\hline Biogroup name & Direction & P value \\
\hline Response to nutrient & down & 0.0053 \\
Protein kinase regulator activity & up & 0.0053 \\
Carbohydrate binding & up & 0.0054 \\
Calcium ion binding & down & 0.0055 \\
Oxidoreductase activity, acting on sulfur & down & 0.0056 \\
group of donors & & \\
Response to hypoxia & down & 0.0057 \\
Transferase activity, transferring aldehyde or & up & 0.0058 \\
ketonic groups & & \\
$\begin{array}{l}\text { Positive regulation of multicellular organismal } \\
\text { process }\end{array}$ & up & 0.0059 \\
Xenobiotic transporter activity & & \\
Xenobiotic-transporting ATPase activity & up & 0.0063 \\
Phospholipase inhibitor activity & up & 0.0063 \\
\hline
\end{tabular}

Notes: Functional groupings of the modulated genes were determined using Gene Ontology classifications in NextBio. The top 200 biogroups most significantly regulated by DAC (at $3 \mu \mathrm{M})$ are shown.

\section{Publish your work in this journal}

Lung Cancer: Targets and Therapy is an international, peer-reviewed, open access journal focusing on lung cancer research, identification of therapeutic targets and the optimal use of preventative and integrated treatment interventions to achieve improved outcomes, enhanced survival and quality of life for the cancer patient. Specific topics covered in the journal include:
Epidemiology, detection and screening; Cellular research and biomarkers; Identification of biotargets and agents with novel mechanisms of action; Optimal clinical use of existing anticancer agents, including combination therapies; Radiation and surgery; Palliative care; Patient adherence, quality of life, satisfaction; Health economic evaluations. 